\title{
Between the Alb and the Alps - The fauna of the Upper Cretaceous Sandbach Formation (Passau region, southeast Germany)
}

\author{
SIMON SCHNEIDER, BIRGIT NIEBUHR, MARKUS WILMSEN \& RADEK VodRÁŽKA
}

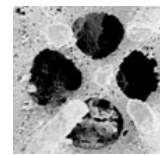

\begin{abstract}
Situated halfway between the Franconian Alb and the Northern Calcareous Alps, the uppermost Turonian to basal Middle Coniacian sediments of the Sandbach Formation (Ortenburg-Passau area, Lower Bavaria) provide valuable information on an area largely devoid of Cretaceous sediments at the surface. Based on the rediscovered classic collection of Gustav von Stockheim, the facies and fauna of the two subunits of the Sandbach Formation, i.e., the Marterberg and Buchleiten members, are described, illustrated, and evaluated with regard to palaeoecology. The fauna comprises 53 taxa in total. Almost two-thirds of these are bivalves, which also dominate the eutrophic distal inner shelf assemblage of the Marterberg Member. Conversely, the mid- to outer shelf fauna of the Buchleiten Member is dominated by siliceous sponges, which flourished on account of continuous deepening and decline of terrigenous input during transgression. $\bullet$ Key words: invertebrate macrofauna, Turonian, Coniacian, palaeoecology, Danubian Cretaceous Group.
\end{abstract}

SCHNEIDER, S., NiEbUhr, B., WiLMSEN, M. \& VodRÁŽKA, R. 2011. Between the Alb and the Alps - The fauna of the Upper Cretaceous Sandbach Formation (Passau region, southeast Germany). Bulletin of Geosciences 86(4), 785-816 (14 figures). Czech Geological Survey, Prague. ISSN 1214-1119. Manuscript received April 14, 2011; accepted in revised form July 15, 2011; published online October 14, 2011; issued November 16, 2011.

\begin{abstract}
Simon Schneider (corresponding author), Bayerische Staatssammlung für Paläontologie und Geologie, Richard-Wagner-Straße 10, D-80333 München, Germany; Naturhistorisches Museum Wien, Department of Geology \& Palaeontology, Burgring 7, A-1010 Wien; simon.schneider@nhm-wien.ac.at•Birgit Niebuhr, Markus Wilmsen, Senckenberg Naturhistorische Sammlungen Dresden, Museum für Mineralogie und Geologie, Sektion Paläozoologie, Königsbrücker Landstraße 159,D-01109 Dresden, Germany; niebuhr.birgit@googlemail.com, markus.wilmsen@senckenberg.de - Radek Vodrážka, Academy of Sciences of the Czech Republic, Institute of Geology, Rozvojová 269, CZ-16502 Praha 6, Czech Republic; Radek.Vodrazka@seznam.cz.
\end{abstract}

The extra-Alpine Cretaceous strata of Bavaria (southern Germany) crop out in the area between Neuburg an der Donau in the northwest and Passau in the southeast, with a centre in the Regensburg region. These deposits have recently been assembled in the Danubian Cretaceous Group by Niebuhr et al. (2009) and represent a classic subject of stratigraphic investigations in Germany. As early as in the $19^{\text {th }}$ century, Geinitz (1850) and Gümbel (1854, 1868a, $1868 \mathrm{~b}, 1891)$ developed an initial litho- and biostratigraphic scheme for these strata. This was followed by a comprehensive treatment of several Upper Cretaceous macrofaunas during the first half of the $20^{\text {th }}$ century, including illustrations of a majority of the taxa recorded (Lehner 1924, 1933, 1937a, b; Dacqué 1939). Since then, the macrofauna of the Danubian Cretaceous Group has hardly received any further scientific attention. Presumably, the loss of several significant collections of Cretaceous fossils from Bavaria during World War II represents the key reason for this lack of scientific activity. Except for a small suite of specimens mainly from the Cenomanian-lower Lower Turonian Regensburg and Eibrunn formations, the collections of Edgar Dacqué, Joseph Egger, and Ferdinand Trusheim, which were held by the Bayerische Staatssammlung für Paläontologie und Geologie (BSPG, München) and the Geologische Sammlung at the Landesamt für Umwelt (LfU, München) must be considered lost (Tröger et al. 2009, Wilmsen et al. 2009, Wilmsen \& Niebuhr 2010). The major portion of Trusheim's collection was housed at the Naturkundemuseum Ostbayern (Regensburg), which was completely destroyed in the 1940s. Moreover, since mining has ceased, most of the outcrops of Cretaceous strata have become overgrown, and hence comprehensive collections from the late $20^{\text {th }}$ and early $21^{\text {st }}$ century are rare.

Knowing about this deficiency of documentation with respect to most subunits of the Danubian Cretaceous Group, it came as a great surprise that the entire collection of Gustav Freiherr von Stockheim, donated to the "Königliches Naturalienkabinett" at Dresden (now Senckenberg 


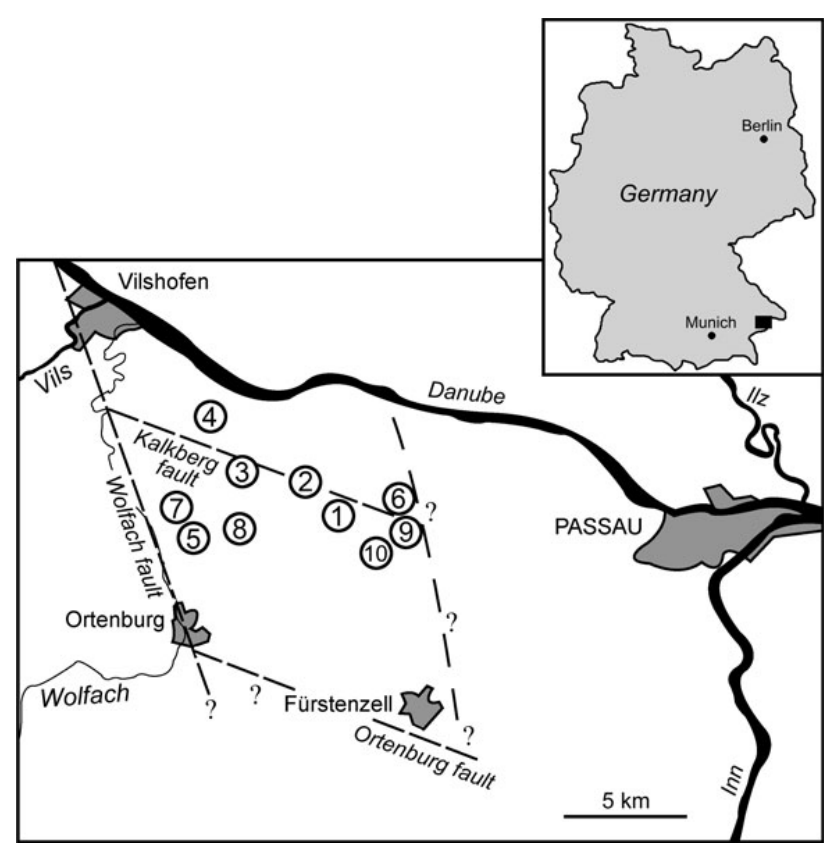

Figure 1. Geographical overview, including (supposed) faults that define the "Ortenburger Senkungsfeld". The localities are indicated by numbers, as follows: 1 - forested hill slope S of Kalkberg Quarry, N Untervoglarn; 2 - Giglmörn/Giglmörgen; probably identical with "lower part of Sandbach valley" of other authors; 3 - Marterberg; 4 - Limekiln of Aichberger/Eichberger near Hausbach; 5 - Buchleiten, at the base of Schöfbach valley; 6 - creek S of Mahd; 7 - Gieshübl 2 Borehole; 8 - Ortenburg B 1 Borehole; 9 - Straß Borehole; 10 - well near Kemating.

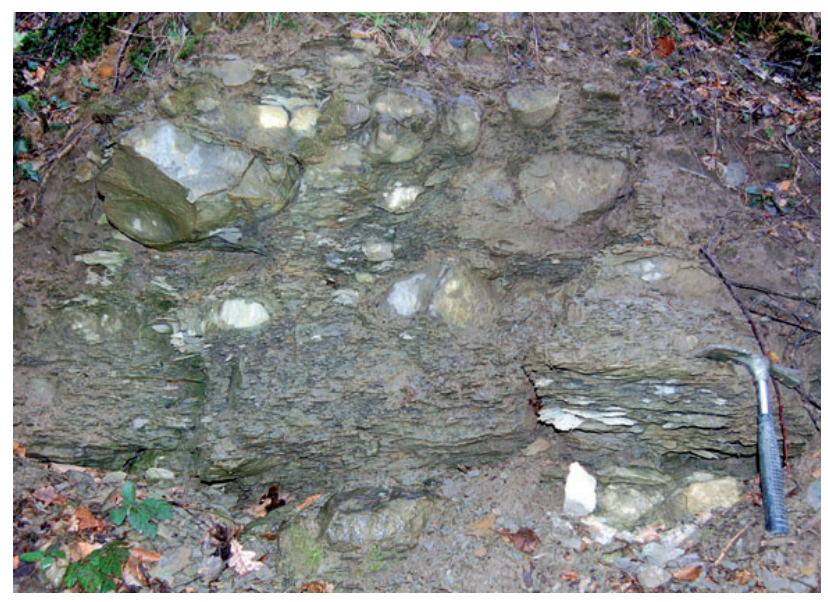

Figure 2. Outcrop of the Buchleiten Member at forested hill slope S of Kalkberg Quarry, N Untervoglarn (locality 1 in Fig. 1). Layers and nodules of marly limestone intercalated with platy or laminated marls.

Naturhistorische Sammlungen Dresden, Museum für Mineralogie und Geologie; MMG) in 1851, is still preserved in excellent condition. This suite of fossils consists of more than 200 specimens that were collected from the upper Upper Turonian to basal Middle Coniacian Sandbach Formation, formerly known as "Ortenburger
Kreide" (Niebuhr \& Schneider in Niebuhr et al. 2009), and forms the basis for this study.

Although they provide important information on the Cretaceous System in the region between the Franconian Alb and the Alps, the sediments of the Sandbach Formation are much less thoroughly studied than most other subunits of the Danubian Cretaceous Group, and only a small selection of fossils has ever been depicted as drawings (see historical background below). Consequently, the "rediscovery" of the Stockheim collection - the only suite of fossils preserved from the strata in question - provides a unique research opportunity. The present study aims at (1) the documentation of the fauna of the Sandbach Formation and (2) a palaeoecological characterisation of the assemblages. All taxa that can be addressed at least at family level are illustrated, and those not previously discussed by Tröger $e t$ al. (2009) and Wilmsen et al. (2009) are briefly described.

\section{Historical background}

The sediments of the Sandbach Formation have received only minor scientific attention to date. On the one hand, this is certainly due to the poor outcrop situation. In the $19^{\text {th }}$ century, however, Cretaceous marls and clays were mined in a few relatively small-sized pits (e.g., at Marterberg and Buchleiten; Fig. 1) to be used as fertiliser for the barren soils of the area. Usually, mining was executed only during winter, because the sediments were soaked with water and could only be handled when frozen (Kraus 1915). With the rise of industrial fertilisers in the $20^{\text {th }}$ century, mining ceased, and the outcrops were restored or simply became overgrown. Today, a single natural outcrop exists along a forested hill slope, where small patches of marly limestone are accessible (Fig. 2). On the other hand, the preservation of a major part of the fossil fauna from the Sandbach Formation is relatively poor, which prevents a detailed taxonomic attribution of part of the taxa (see systematic palaeontology below).

Despite these drawbacks, several scholars have studied Cretaceous fossils from the Ortenburg region. The first one to report on these strata was Josef Waltl (1847), who briefly mentioned fossiliferous Cretaceous sediments from the surroundings of Passau. Ludwig Wineberger (1851, p. 83) gave a short description of the sediments, together with a list of fossils that was compiled by Gustav von Stockheim and Hanns Bruno Geinitz. The following year, Stockheim (1852) published a more extensive list of taxa and compared the fauna from Marterberg and Buchleiten with those from the Regensburg region and from Bohemia. During 1851, Stockheim sent several packages of fossils from Marterberg and Buchleiten to the "Königliches Naturalienkabinett" at Dresden, which was then under the care of Hanns Bruno Geinitz. According to his correspon- 
dence to Geinitz (now kept in the Hauptstaatsarchiv Dresden), the latter assisted with determinations and probably returned some of the specimens afterwards. It remains unclear whether or not the specimens now preserved at Dresden represent Stockheim's entire collection.

Wilhelm von Gümbel (1868b, pp. 458-459, 723, 724) presented a detailed characterisation of the Cretaceous rocks west of Passau. In his stratigraphic scheme, however, he mistakenly regarded the "Marterberger Schichten" as younger than the "Buchleitener Schichten", and thus the correlation of the Passau and Regensburg regions remained erroneous until the biostratigraphy was revised by Tröger et al. (2009). Moreover, Gümbel (1868b) published an extensive list of the fauna and figured two small cardiids (one of them described as a new species) and an oyster (also described as new) from the Marterberg marls. The latest and most comprehensive treatment of the fauna was conducted by Oskar Carl Gerster (1881), who provided short descriptions and comparisons of the fossils, and recorded a significantly larger number of taxa than Stockheim (1852). Moreover, he introduced three new species of hexactinellid and lithistid sponges, which he figured on a hand-drawn plate. A single ostracod species from Marterberg was reported by Egger (1907). Subsequently, several scholars published more or less brief descriptions of the Cretaceous sediments, mostly in the course of general treatments of the geology of the area, however, without adding new observations (Kraus 1915, Schreyer 1967, Unger 1984). Recently, the lithostratigraphy has been updated, and the Sandbach Formation, including the lower Marterberg Member, consisting of dark, sandy marls, and the upper calcareous Buchleiten Member, was formally established (Niebuhr \& Schneider in Niebuhr et al. 2009). Moreover, the inoceramid bivalves (Tröger et al. 2009) and, to some extent, the ammonoids (Wilmsen et al. 2009) from the Sandbach Formation were studied in detail, with regard to both taxonomic and stratigraphic issues, and most of the material was figured.

\section{Geological setting}

During the early Late Cretaceous, one of the most pronounced eustatic sea-level rises of the Phanerozoic Eon occurred (e.g., Hancock \& Kauffman 1979, Hallam 1992), resulting in the flooding of vast continental areas and their transformation into peri- and epi-continental shelf seas across Europe (e.g., north of the Early Cretaceous Tethys) and elsewhere. As a part of the WNW-ESE-trending MidEuropean Island, the Bohemian Massif remained emergent throughout this transgressive period, but widespread shallow-marine deposits onlapped its margins. In Bavaria, this onlap is exemplified by the Danubian Cretaceous Group (Niebuhr et al. 2009). The twelve formations of this

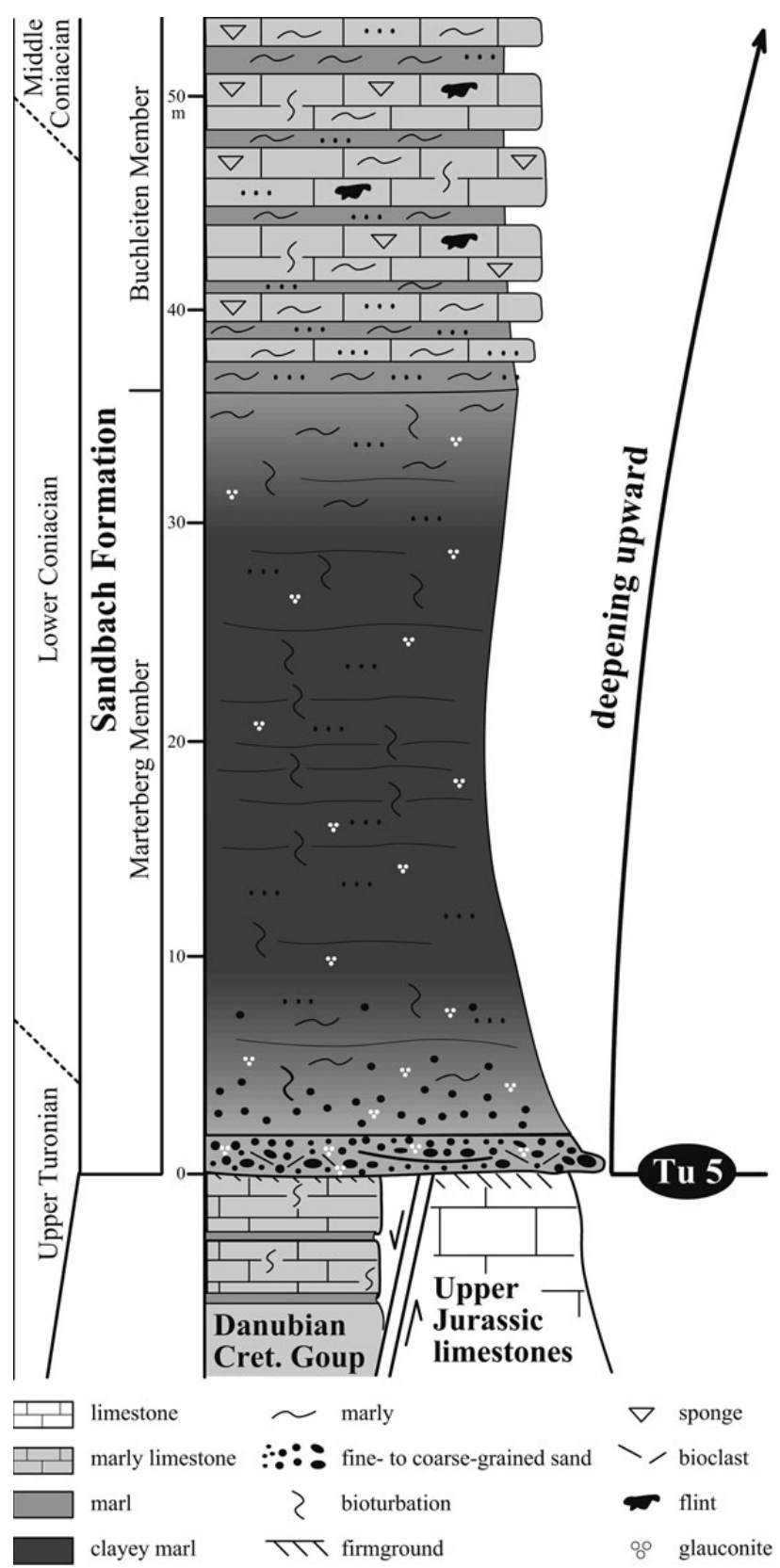

Figure 3. Schematic section of the Sandbach Formation. Tu $5=$ sequence boundary Turonian 5 of Niebuhr et al. (2011). Note the deepening-upward trend shown by the lithofacies of the Sandbach Formation.

300-500 m thick succession were deposited in non-marine to neritic environments and comprise conglomerates, sandstones, clays, marls, calcarenites, siliceous opoka, and limestones. The marine transgression started during the early Early Cenomanian in the southwestern, more distal part of the depositional area (Tröger et al. 2009, Wilmsen \& Niebuhr 2010) and finally (approximately 6 Ma later) reached the proximal Bodenwöhrer Senke during the latest Cenomanian to earliest Turonian. This development is exemplified by the sediments of the strongly diachronous 
Regensburg Formation (Wilmsen et al. 2010). With minor fluctuations, transgression and corresponding deepening of the depositional environment continued during the Early and Mid Turonian, until the maximum flooding interval of the Danubian Cretaceous Group occurred in the late Mid Turonian (Pulverturm Member of the Kagerhöh Formation; Niebuhr et al. 2009, 2011). A significant mid-Upper Turonian sequence boundary is indicated by the erosional incision of the middle Upper Turonian Großberg Formation into the Kagerhöh Formation. Subsequently, a second phase of transgression started above sequence boundary Tu 5 of Niebuhr et al. (2011), which is documented by the deposition of the upper Upper Turonian to Lower Coniacian clays and marls of the Hellkofen Formation and the glauconitic, mica-rich, fine-grained quartz sandstones of the Middle Coniacian Jeding Formation (Niebuhr 2011) in the Bodenwöhrer Senke. Marine Cretaceous strata of post-Coniacian age only occur in the subsurface south of Regensburg underneath a thick sedimentary cover of the Alpine Foreland Molasse, and grade southwards into the pelagic facies of the Alpine Cretaceous.

The Sandbach Formation west of Passau represents a southeasterly outlier of the Danubian Cretaceous Group (see Niebuhr et al. 2009, fig. 1), which parallels the marine Hellkofen and Jeding formations and is time-equivalent to the terrestrial Hessenreuth Formation. The sediments of the Sandbach Formation are characterised by a conspicuously high mica content, which suggests an increased uplift of the source areas during the latest Turonian-Coniacian. The Sandbach Formation is preserved mainly within a rhomb-shaped, tectonically-delimited subsidence structure, the "Ortenburger Senkungsfeld" (Fig. 1; Unger \& Schwarzmeier 1982, Unger 1984). All former outcrops are situated along the faults bordering this structure, while the Cretaceous sediments in the centre of the Ortenburger Senkungsfeld are unconformably overlain by Neogene and Quaternary rocks (Unger 1984; S.S., pers. obs.). Details of tectonic structures of the area are still insufficiently known.

In particular, the following localities, all indicated in Fig. 1, have been reported to expose the Sandbach Formation: (1) Sandbach valley (several pits) and forested hill slope S of Kalkberg Quarry, N Untervoglarn (Gümbel 1868b, Gerster 1881, Kraus 1915, Keim et al. 2004, S.S., pers. obs.). (2) Giglmörn (termed Giglmörgen by Gümbel $1868 \mathrm{~b}$ and Gerster 1881); probably identical with the lower part of Sandbach valley. (3) Marterberg (Stockheim 1851, Gümbel 1868b, Kraus 1915). (4) Limekiln of Aichberger (also Eichberger) near Hausbach (Gerster 1881, Gümbel 1868b). (5) Buchleiten, at the base of the Schöfbach valley (Stockheim 1851, Gümbel 1868b, Gerster 1881, Kraus 1915). (6) Creek S of Mahd (S.S., pers. obs.). Additionally, three boreholes accessed the sediments of the Sandbach Formation: (7) the Gieshübl 2 Borehole at the margin of the "Ortenburger Senkungsfeld" (Unger 1984, p. 231), (8) the Ortenburg B 1 Borehole in the centre of the "Ortenburger Senkungsfeld" (Unger 1984, p. 222), and (9) the Straß Borehole (Schneider 2008). Moreover, Cretaceous marls have been reported from (10) a well near Kemating (D. Jung, Hof, pers. comm.).

Beyond this area, the Cretaceous strata of the Passau region have been eroded. Consequently, the outcrops of the Sandbach Formation occur isolated from both Alpine and other extra-Alpine Cretaceous sediments. Due to the fact that these sediments represent the southernmost extension of the extra-Alpine Cretaceous of Bavaria, their facies, macrofauna, and stratigraphy are of major significance for regional correlation and palaeo(bio-)geography.

\section{Material and methods}

At present only a single, small outcrop of the Sandbach Formation is accessible along a forested hill slope south of the Kalkberg Quarry near Untervoglarn (locality 1, Figs 1, 2). In 2009, the senior author (S.S.) collected a few rock samples from the Buchleiten Member at this locality which yielded a single specimen of the bivalve Cucullaea and a siliceous sponge (MMG: BaK 166, 167). Moreover, several isolated boulders of glauconitic marlstone of the Marterberg Member, found in a little creek at Mahd immediately to the north of the Kalkberg Quarry (locality 6, Fig. 1), contained several moulds of the gastropod Turritella and a single specimen of the bivalve Cercomya (deposited at the Bayerische Staatssammlung für Paläontologie und Geologie, München; BSPG 2002 XIII 367). Apart from these finds, the present study is based on the collection of Gustav von Stockheim, comprising three drawers of material deposited in the palaeozoology collection of the Senckenberg Naturhistorische Sammlungen Dresden, Museum für Mineralogie und Geologie (MMG), Sektion Paläozoologie, repository $\mathrm{BaK}$

Figure 4. Microfacies of the Sandbach Formation. • A-E - Buchleiten Member. A - lychniscosidan sponge Tremabolites sp., MMG: BaK 167, width of photomicrograph $=30 \mathrm{~mm}$. B - spiculitic calcisphere wacke- to packstone with spicules of soft (loose-spicule) demosponges, ostracods, inoceramid bivalve prisms, bryozoans, and echinoderm debris, width of photomicrograph $=4 \mathrm{~mm}$. $\mathrm{C}$, E - details of siliceous, regular lychniscosidan framework of Fig. 4A, width of photomicrograph $=4 \mathrm{~mm}$. D - secondarily enlarged axial channels of large monaxons are filled with matrix-glauconite and embedded in a spiculitic calcisphere wacke- to packstone, width of photomicrograph $=4 \mathrm{~mm}$. $\bullet \mathrm{F}-\mathrm{H}-$ Marterberg Member. F - calcareous cemented spiculitic sandstone with dark bioturbation, width of photomicrograph $=30 \mathrm{~mm} . \mathrm{G}$ - lithoclastic wacke- to packstone with badly sorted angular quartz grains and clusters of white mica, width of photomicrograph $=30 \mathrm{~mm}$. $\mathrm{H}$ - detail of oyster shell in Fig. $4 \mathrm{G}$, width of photomicrograph $=4 \mathrm{~mm}$. 


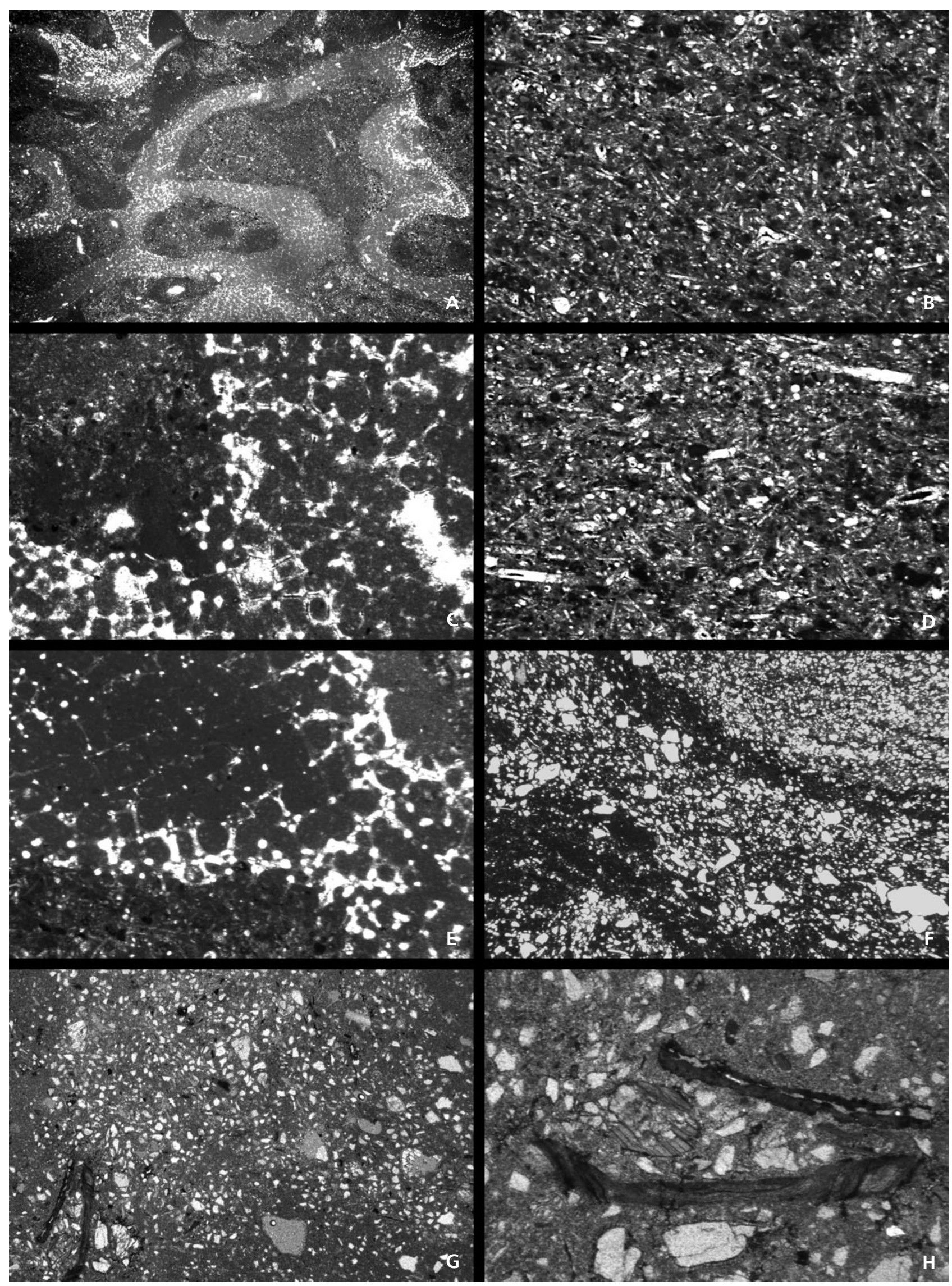


("Bavarian Cretaceous"). This collection is not yet fully registered (e.g., three specimens, but only two numbers), or several specimens of one species are pooled under one number (e.g., MMG: BaK 96/1, 2, 97/1-3). From the rock samples collected at Untervoglarn, several thin sections were prepared to study the microfacies (B.N., private collection). For photography, the macrofossils were coated with ammonium chloride. Part of the silicified sponge skeleton was treated in $3 \%$ hydrochloric acid and studied using standard methods of scanning electron microscopy (Jeol JSM-6380).

\section{Facies}

The Sandbach Formation is subdivided into two members with different litho- and biofacies (Fig. 3), formerly referred to as the "Marterberger Schichten" and the "Buchleitener Schichten" (Niebuhr \& Schneider in Niebuhr et al. 2009). The lower Marterberg Member reaches a thickness of several metres (exact data are still lacking; Unger 1984) and consists of dark grey sandy marls and marly sandstones with coarse angular quartz grains, clusters of white mica, and $\mathrm{ca} 5 \%$ of glauconite (Fig. 4F-H). Based on geochemical analysis, contents of $70 \% \mathrm{SiO}_{2}$ and slightly less than $10 \% \mathrm{CaCO}_{3}$ were determined (Gümbel 1868b, p. 461). The rich and diverse macrofauna of the Marterberg Member is dominated by bivalves.

The upper Buchleiten Member reaches more than $15 \mathrm{~m}$ in thickness (Niebuhr \& Schneider in Niebuhr et al. 2009) and is lithologically similar to the typical "Plänerkalke" of northern Germany (see Niebuhr et al. 2007). It consists mainly of splintery, bioturbated, marly limestones that are light grey and yellowish mottled in colour. Certain layers are spongiolithic and yield small flint nodules. Microfacies analyses revealed spiculitic calcisphere wacke- to packstones containing spicules of soft demosponges, ostracods, inoceramid bivalve prisms, bryozoans, and echinoderm debris (Fig. 4B, D), as well as regular lychniscosan frameworks (Fig. 4A, C, E). The macrofauna of the Buchleiten Member is less rich than that of the Marterberg Member, and is dominated by siliceous sponges and bivalves.

The uppermost Turonian glauconitic sediments at the base of the Marterberg Member of the Sandbach Formation transgressed on Upper Jurassic limestones along the borders of the "Ortenburger Senkungsfeld" or older sediments of the Danubian Cretaceous Group in its centre (Unger 1984, Niebuhr \& Schneider in Niebuhr et al. 2009). The same is true for the Straubing area between Passau in the southeast and Regensburg in the northwest (e.g., Dacqué in Rothpletz 1911). This transgression is probably related to the development of a marginal trough, which resulted from the contemporaneous uplift of the southeastern margin of the Bohemian Massif along the Donaurandbruch (compare Niebuhr et al. 2011). During the early Early Coniacian, terrigenous input and sedimentation rates were high. With continuing transgression, the sedimentation gradually passed over into the Buchleiten Member during the middle Early Coniacian. Terrigenous input decreased and hence biogenic carbonate forms the dominant component of these marly limestones. Sedimentation occurred with lowered rates in a more distal environment, at a presumed water depth of several tens of metres. The entire succession of the Sandbach Formation exemplifies a deepening-upward cycle, grading from nearshore greensand facies at the base via inner shelf sandy-silty marls (Marterberg Member) into mid-shelf Pläner limestones (Buchleiten Member) (Fig. 3). A similar transgressive sequence has been described by Wilmsen et al. (2005) from the Cenomanian of northern Germany.

\section{Stratigraphy}

Inoceramid bivalves occur in all marine facies of the Danubian Cretaceous Group and are thus of prime importance for the biostratigraphic subdivision of these strata (Tröger et al. 2009, Niebuhr 2011). The Sandbach Formation yielded eight species of inoceramids, assigned to five different genera. A single species, i.e., Cremnoceramus crassus cf. cripsioides (Elbert), is shared by both members. The Marterberg Member yields Rhyssomytiloides? sp., Inoceramus cf. vistulensis Walaszczyk, Cremnoceramus rotundatus (Fiege) sensu Tröger (1967) and Cremnoceramus waltersdorfensis hannovrensis (Heinz), which indicate a lower Lower Coniacian age, while Mytiloides mytiloidiformis (Tröger) is more indicative of a late Late Turonian age. For the Buchleiten Member a time interval from the middle Early Coniacian to the Early/Middle Coniacian boundary is supported by the occurrence of Cremnoceramus deformis erectus (Meek) and Platyceramus sp. ex gr. mantelli (de Mercey) (Tröger et al. 2009).

\section{Systematic palaeontology}

The present study intends to provide an overview of the fauna from the Sandbach Formation. The inocermid bivalves (Tröger et al. 2009) have recently been treated in detail, and are therefore only listed and figured herein for completeness. Many other taxa cannot be determined to species or even genus level, due to poor preservation, and are therefore only briefly characterised. The authors of higher rank systematic categories have not been included in the references.

Phylum Foraminifera d'Orbigny, 1826

Class Polythalamea Ehrenberg, 1838

Order Lagenida Delage \& Hérouard, 1896 
Family Vaginulinidae Reuss, 1860

\section{Neoflabellina suturalis suturalis (Cushman, 1935)} Figure 5A-C

* 1935 Flabellina suturalis Cushman; Cushman, p. 673, figs 9-17.

1982 Neoflabellina suturalis suturalis (Cushman, 1935). Hercogova, p. 115, pl. 10, figs 3-5, pl. 11, figs 1-4.

Material. - 5 specimens, Buchleiten Member (MMG: BaK 71/1-4, 85).

Remarks. - This subspecies may attain lengths of over $2 \mathrm{~mm}$, while other subspecies are significantly smaller, as are other species of the genus Neoflabellina. The specimens from the Buchleiten Member closely resemble the slender (i.e., stratigraphically older) individuals from several outcrops and wells in Bavaria figured by Ohmert (1969). In the Bohemian Cretaceous Basin, N. s. suturalis first appears in the upper part of the Lower Coniacian and ranges into the Upper Coniacian (Hercogova 1982). This compares well to the occurrence in the Sandbach Formation. In northern Germany, N. suturalis (Cushman) first appears in the Middle Coniacian of the chalk standard section Lägerdorf (Schönfeld 1990, p. 135), which approximately corresponds to the Buchleiten Member in age. In the extra-Alpine Cretaceous strata of Bavaria (Ohmert 1969) and Austria (Wessely et al. 1981) it first occurs in the Upper Coniacian.

Phylum Porifera Grant, 1836

Remarks. - The sponge classification used in this paper follows Systema Porifera (Hooper \& Van Soest 2002), a recognised authoritative reference for sponge taxonomy.

Class Hexactinellida Schmidt, 1870

Subclass Hexasterophora Schulze, 1886

Order Hexactinosida Schrammen, 1903

Family Cribrospongiidae Roemer, 1864

\section{Hillendia bohemica (Počta, 1883)}

Figure 6A-E

non 1877a Pleurostoma Bohemicum Zitt. n. sp. (nomen nudum); Zittel, p. 22.

non 1877b Pleurostoma Bohemicum Zitt. n. sp. (nomen nudum); Zittel, p. 48.

? 1881 Leptophragma ramosum m. (nomen oblitum); Gerster, pp. 23, 24, pl. 1, figs 1-5.

* 1883 Pleurostoma bohemicum Zitt. - Počta, p. 21, text fig. 7 , pl. 2, fig. 7 .

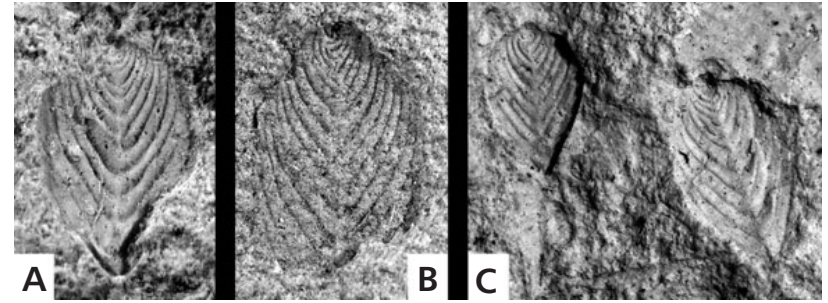

Figure 5. Foraminifera. Neoflabellina suturalis suturalis (Cushman, 1935), Buchleiten Member. • A - MMG: BaK 85, width of photomicrograph $=32 \mathrm{~mm}$. $\cdot \mathrm{B}-\mathrm{MMG}$ : BaK 71/1, width of photomicrograph $=$ $30 \mathrm{~mm}$. $\bullet$ C - MMG: BaK 71/2+3, width of photomicrograph $=45 \mathrm{~mm}$.

1889 Pleurostoma bohemicum Zitt. - Frič, p. 103, text fig. 138.

1913 Pleurostoma bohemicum Zitt. - Scupin, p. 261, pl. 15 , fig. $14 \mathrm{a}, \mathrm{b}$.

1933 Pleurostoma dichotomum Schramm. - Rauff, pp. 31, 32, pl. 1, fig. $14 \mathrm{a}$, b.

1964 Hillendia polymorpha gen. et sp. nov.; Reid, pp. 64, 67 , text fig. $33 \mathrm{a}, \mathrm{b}$.

Material. - 3 specimens, Buchleiten Member (MMG: BaK 21, 88).

Description. - Body variable in form, forming saccular growths and/or tubular to bilaterally compressed branches (Fig. 6A, B). Dictyonal skeleton formed by three-dimensional hexactinosidan dictyonal framework with radial, blind canals arranged quincuncially at outer (dermal) surface (Fig. 6C-E).

Remarks. - The spiculation, arrangement and density of canals, and general morphology leave no doubt that the studied specimens belong to the genus Hillendia, which was erected by Reid (1964) for cribrospongiid hexactinellid sponges showing a skeletal organization identical to that of Guettardiscyphia de Fromentel, 1860, but differing from the latter in the presence of bilaterally compressed to irregularly branched outgrowths. The skeletal organisation and gross morphology of the studied specimens correspond to those of Hillendia bohemica (Počta, 1883) (= Pleurostoma bohemicum Zittel, 1877, nomen nudum), which is synonymised herein with Hillendia polymorpha Reid, 1964.

Leptophragma ramosum Gerster, 1881 (nomen oblitum; holotype lost; Gerster 1881, pl. 1, figs 1-5) is most probably identical with the studied material from the Stockheim collection. Gerster (1881) himself observed the striking similarity of L. ramosum "with Pleurostoma Bohemicum Zitt. n. sp.", but separated his species because of (1) the lack of parietal oscula on branching outgrowths and (2) the seemingly irregular arrangement of canal openings. Nonetheless, scarcity to absence of parietal oscula, especially on tubular outgrowths, as well as a seemingly irregular arrangement of canal openings was also observed in Hillendia bohemica (Reid 1964, Vodrážka 2005). 


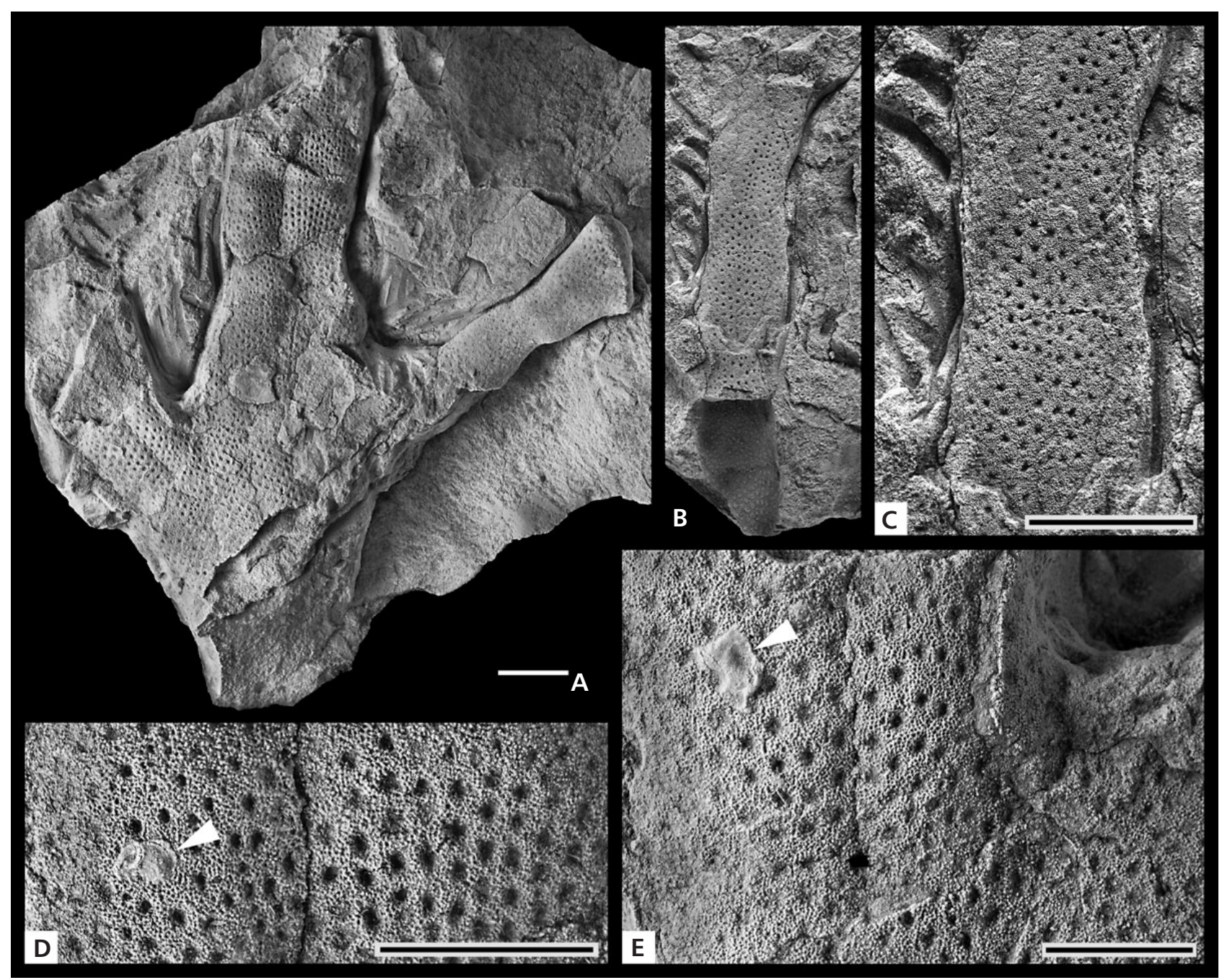

Figure 6. Porifera. Hillendia bohemica (Počta, 1883), Buchleiten Member. • A - tubular growth with bilaterally compressed branch. Right-hand, finger-like outgrowth is a fragment of a second individual, MMG: BaK 21. $\bullet$, C - finger-like outgrowth representing fragment of a complex and branching skeleton, MMG: BaK 88; B - general view, C - detail of dictyonal skeleton of dermal (outer) surface with incurrent (inhalant) canals. $\bullet$ D, E - details of Fig. 4A. Dermal surface with incurrent canals arranged in typical quincuncial pattern. Outer sponge skeleton surfaces are colonised by juvenile oysters (arrows). Scale bars A-C $=10 \mathrm{~mm}, \mathrm{D}, \mathrm{E}=5 \mathrm{~mm}$.

Hillendia bohemica occurs in the Middle TuronianMiddle Coniacian of the Czech Republic (e.g., Počta 1883, Vodrážka 2005, Vodrážka et al. 2009), Poland (Pleurostoma bohemicum Zittel in Scupin, 1913), Germany (Pleurostoma dichotomum Schrammen in Rauff 1933) and England (Hillendia polymorpha gen. et sp. nov. in Reid 1964).

Order Lychniscosida Schrammen, 1903

Family Neoaulocystidae Zhuralevleva, 1962

\section{Tremabolites sp.}

Figures 4A, C, E, 7A-F

Material. - 1 specimen, Buchleiten Member (MMG: BaK 167). The specimen was sectioned (Fig. 4A, C, E) and one fragment was treated in hydrochloric acid in order to obtain a three-dimensionally preserved siliceous skeleton for SEM studies (Fig. 7).

Description. - Nodular skeleton composed of divided and anastomosed irregular tubes (Fig. 4A). Tube walls consist of regular, primary (choanosomal) framework (Fig. 7E) with smooth or slightly tuberculate hexactins with distinct nodal octahedra (Fig. 7D). Etched fragment of the skeleton exhibits apertures between divided and anastomosed tubes on the sponge surface; these apertures are denticulate or partly enclosed by spinose outgrowths (Fig. 7A). Outgrowths $(0.5-4 \mathrm{~mm}$ in length) radiate from elevated tube walls on the sponge surface. Elevated tube walls also bear small parietal oscula 0.3 to $3.5 \mathrm{~mm}$ in diameter (Fig. 7A, F). Parietal oscula and apertures between tubes 


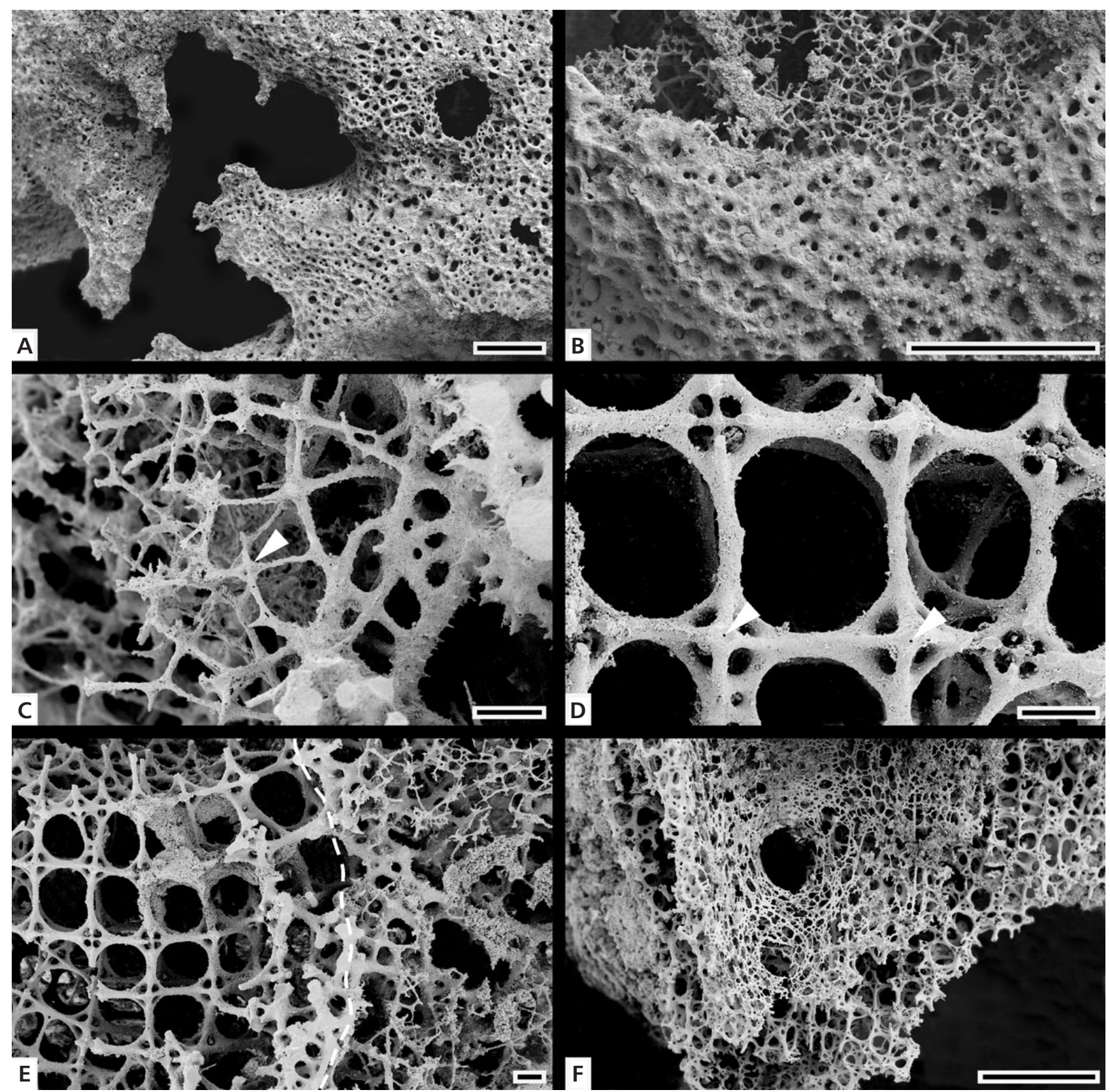

Figure 7. Porifera. Tremabolites sp., MMG: BaK 167, Buchleiten Member, SEM photomicrographs. $\bullet$ A - sponge surface exhibiting aperture between anastomosed tubes partly enclosed by spinose outgrowths (left) and parietal oscula protruding elevated tube wall (right). $\bullet$ - cortical meshwork on the outer (dermal) surface with tuberculate, secondarily enlarged hexactins. Parietal osculum (top) is veiled by irregular secondary meshwork. $\bullet \mathrm{C}-$ irregular secondary meshwork formed by hexactins with (arrow) or without nodal octahedra. Note tubercules and spines on secondarily enlarged primary framework (right). $\bullet \mathrm{D}$ - regular, primary (choanosomal) framework consisting of smooth to slightly tuberculate hexactins with distinct nodal octahedra. Note axial channels in the centre of fragmented beams (arrows). E - primary framework within wall (left) with secondarily enlarged hexactins near gastral surface (dashed line) and gastral surface of the wall (right) with meshwork consisting of siliceous filaments and small accretive hexactins. $\bullet F-$ fragment of the tube wall exhibiting gastral surface protruded by parietal oscula (centre). Note irregular, secondary meshwork on gastral surface formed by siliceous filaments veiling regular, primary framework. Scale bars: A, B, F $=1 \mathrm{~mm} ; \mathrm{C}-\mathrm{E}=0.1 \mathrm{~mm}$.

locally veiled by accumulation of irregular secondary meshwork (Fig. 7B, C) formed by considerably smaller hexactins with or without nodal octahedra (Fig. 7C). Cortical meshwork on the outer (dermal) surface formed by tuberculate, secondarily enlarged hexactins with intensively ob- literated nodal octahedra (Fig. 7A, B, C). Internal (gastral) surface of tube walls shows tuberculate, secondarily enlarged, outermost primary framework (Fig. 7E), veiled by anastomosed siliceous filaments with incorporated small hexactins (Fig. 7E, F). 
Remarks. - The fragment of three-dimensional framework exhibits a skeleton that is typical of the lower part of Tremabolites. This is also supported by the comparison of the studied material with Upper Turonian Tremabolites specimens from the Bohemian Cretaceous Basin. The studied fragment does not show the typical rigid capsule that is pierced by oscula of tubes; however, this capsule occurs in the uppermost part of the sponge and also may be absent due to taphonomic processes (e.g., Schrammen 1912, pl. 39, fig. 4).

\section{Class Bivalvia Linnaeus, 1758}

Remarks. - Abbreviations used for Bivalvia: L = length; $\mathrm{H}=$ height; $\mathrm{T}=$ thickness; $\mathrm{RV}=$ right valve; $\mathrm{LV}=$ left valve; $\mathrm{CV}=$ specimen with contiguous valves.

Subclass Protobranchia Pelseneer, 1889

Order Nuculida Dall, 1889

Family Nuculidae Gray, 1824

\section{Nucula sp.}

Figure 8K

Material. - 3 specimens, Marterberg Member (MMG: BaK 60).

Remarks. - The specimens are preserved as internal moulds with small remnants of shell, and assignable to $\mathrm{Nu}$ cula mainly because of their typical shape. In one specimen, three taxodont teeth of the anterior part of the hinge are visible (see arrow in Fig. 8K).

Subclass Autobranchia Grobben, 1894

Superorder Pteriomorphia Beurlen, 1944

Order Mytilida Férussac, 1822

Family Mytilidae Rafinesque, 1815

\section{Septifer lineatus (J. de C. Sowerby in Fitton, 1836)} Figure 8A

* 1836 Modiola lineata; J. de C. Sowerby in Fitton, p. 338, pl. 14, fig. 2 .
? 1881 Modiola radiata (Münst.) Rss. sp.; Gerster, p. 14.

1900 Septifer lineatus (Sowerby), 1836 [sic]. - Woods, pp. 106-110, pl. 18, figs 1-12.

For extensive synonymy see Woods (1900).

Material. - 1 specimen, Buchleiten Member (MMG: $\mathrm{BaK} 73)$.

Description. - Single fragment of a left valve, lacking anterior part of shell. Exterior of shell ornamented with $>30$ distinct primary radial ribs, some of them bifurcating towards the ventral margin; several short additional ribs intercalating in ventral shell portion; distinct, irregular growth lines crossing radial ribs, causing a sub-reticulate pattern.

Remarks. - Judging from the shape and ornamentation, the shell fragment could be assigned to several genera, including Arcomytilus, Brachidontes, and Septifer. Based on the relatively coarse ornamentation and the obviously modioliform rather than mytiliform shell shape, an assignment to Septifer lineatus seems most appropriate.

Order Arcida Gray, 1854

Family Arcidae Lamarck, 1809

Barbatia? sp.

Figure 8D

Material. - 3 specimens, Marterberg Member (MMG: BaK 54).

Description. - Shell broad, sub-trapezoidal, only slightly inflated; umbones low and broadly rounded, almost central, orthogyrous; anterior and posterior margin slightly angled, but well rounded. Shell surface ornamented with $>35$ distinct, regular radial ribs with relatively narrow interspaces. Internal shell features unknown.

Remarks. - The specimens are preserved as moulds with parts of the shell retained. The ribbing pattern is distinctly coarser and much more regular than seen in most representatives of Barbatia. Instead, it closely resembles the ornamentation seen usually in Anadara. However, the

Figure 8. Bivalvia: Nuculida and Pteriomorphia excluding Inoceramidae. • A - Septifer lineatus (J. de C. Sowerby in Fitton, 1836 ), MMG: BaK 73. Buchleiten Member. • B - Rastellum diluvianum (Linnaeus, 1767), MMG: BaK 101. Marterberg Member. • C - Lima pseudocardium? Reuss, 1846, MMG: BaK 87. Buchleiten Member. • D - Barbatia? sp., MMG: BaK 54. Marterberg Member. • E, G - Exogyrinae indet., MMG: BaK 75, 79. Buchleiten Member. • F, H - Camptonectes (Camptonectes) virgatus (S. Nilsson, 1827), MMG: BaK 108/1, 108/2. Marterberg Member. • I - Lima multicostata Geinitz, 1839, MMG: BaK 76. Buchleiten Member. $\bullet \mathrm{K}$ - Nucula sp., MMG: BaK 60. Marterberg Member. • L - Lyropecten (Aequipecten?) ternatus (Münster in Goldfuss, 1833), MMG: BaK 100. Marterberg Member. • M - Neithea (Neithea) quinquecostata (J. Sowerby, 1814), MMG: BaK 67. Buchleiten Member. • N - Anomia sp., MMG: BaK 63. Marterberg Member. • O1, 2 - Cucullaea cf. glabra Parkinson, 1811, MMG: BaK 48. Marterberg Member. Scale bars = 10 mm. 


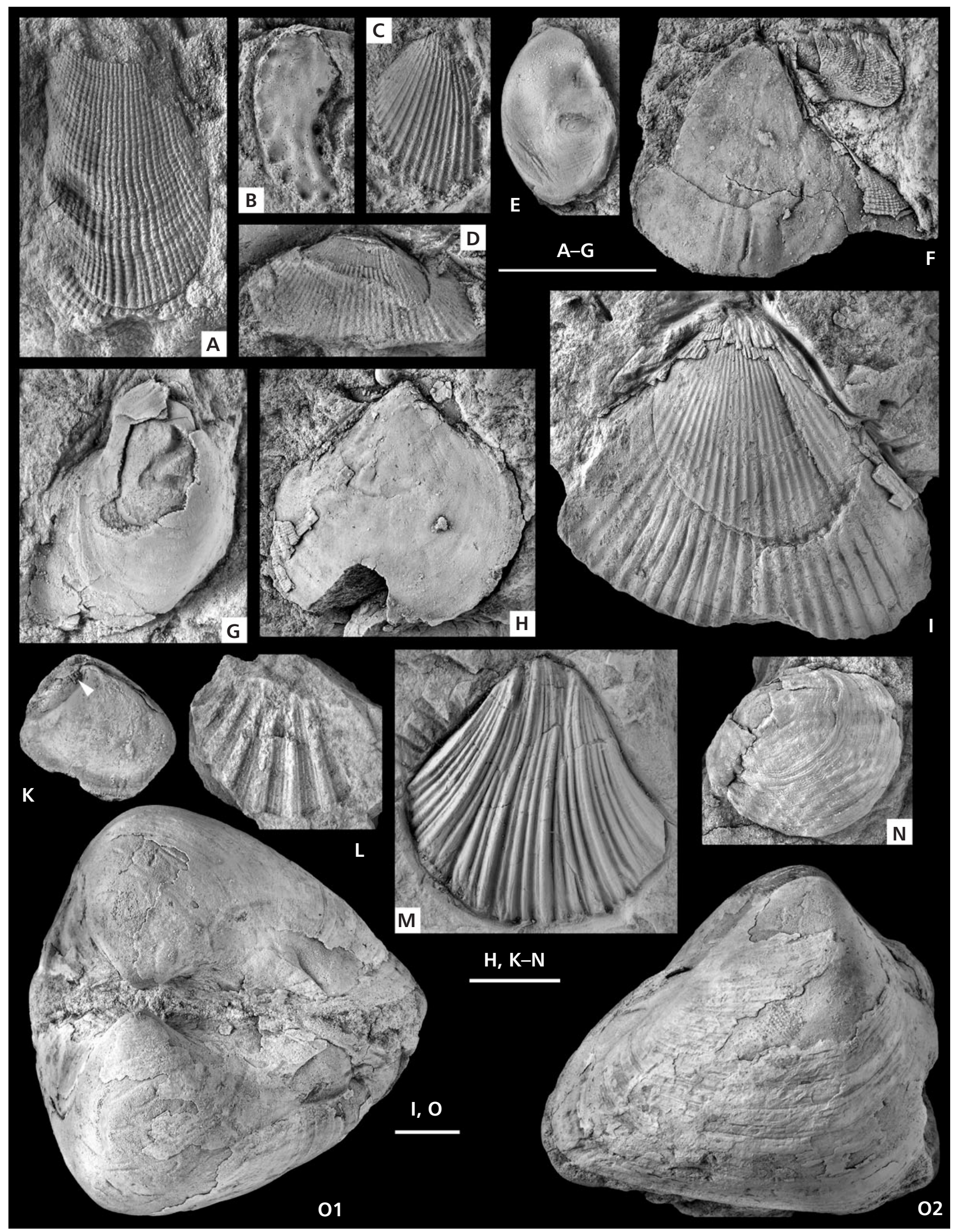


low umbones, rounded anterior and posterior margins, and low inflation argue rather for an assignment to Barbatia. Either decision, however, remains tentative, as internal shell features cannot be assessed.

Family Cucullaeidae Stewart, 1930

\section{Cucullaea cf. glabra Parkinson, 1811}

Figure 80

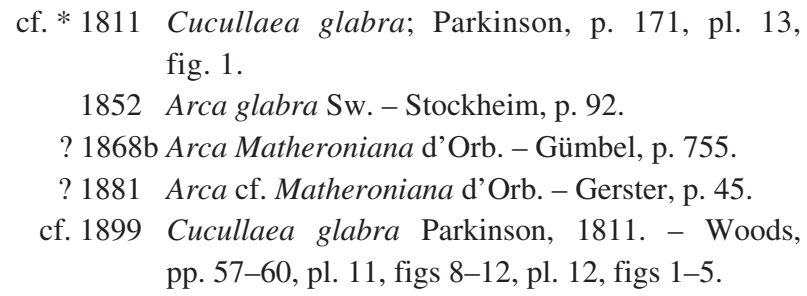
fig. 1.

1852 Arca glabra Sw. - Stockheim, p. 92.

? 1868b Arca Matheroniana d'Orb. - Gümbel, p. 755.

? 1881 Arca cf. Matheroniana d'Orb. - Gerster, p. 45.

cf. 1899 Cucullaea glabra Parkinson, 1811. - Woods, pp. 57-60, pl. 11, figs $8-12$, pl. 12, figs $1-5$.

For extensive synonymy see Woods (1899).

Material. $-2+1$ juv. specimens, Marterberg Member (MMG: BaK 48); 1 specimen, Buchleiten Member (MMG: BaK 166).

Description. - Shell relatively large ( $\mathrm{L}>70 \mathrm{~mm})$, strongly inflated $(\mathrm{L}: \mathrm{T}=1: 1)$, inaequilateral, with slightly tapering posterior ventral corner; anterior dorsal corner distinct but rounded; posterior dorsal and anterior ventral corners almost obsolete and well rounded. Umbones prominent, strongly protruding, relatively narrow-triangular, almost orthogyrous; positioned at about one-third of shell length. Shell growth allometric, with increased growth towards the anterior end, resulting in enhanced inflation with increase in size. Ligament area relatively broad, amphidetic, with larger portion situated behind umbones. Shell rather thin; shell surface smooth, but with distinct irregular growth lines.

Remarks. - Although relatively poorly preserved, the specimens compare closely with the numerous large Cretaceous Cucullaea from Europe. They seem to agree well with those forms reported as C. glabra from Saxony and Bohemia by Geinitz (1840, 1843) and Reuss (1846). However, as already noted by Woods $(1899$, p. 60), these specimens differ from the material from England in a more oblique shell outline and a more pointed umbo; he consequently lists them as dubious synonyms. Moreover, the English material of C. glabra is of Late Aptian age (C.J. Wood, written comm.), and thus significantly older than the specimens from the Sandbach Formation. However, whether or not these are two truly different species can only be decided on the basis of well-preserved specimens. Thus, the individuals from the Sandbach Formation are provisionally assigned to C. glabra.
Order Pteriida Newell, 1965

Family Inoceramidae Giebel, 1852

Remarks. - Two out of 20 inoceramid specimens are indeterminable at genus level, due to poor preservation. The remaining 18 specimens comprise eight species belonging to five genera and have been described in detail by Tröger $e t$ al. (2009) including comprehensive synonymy. Therefore, the Inoceramidae are only briefly treated herein, and a single specimen of each taxon is illustrated.

\section{Inoceramus cf. vistulensis Walaszczyk, 1992}

Figure 9H

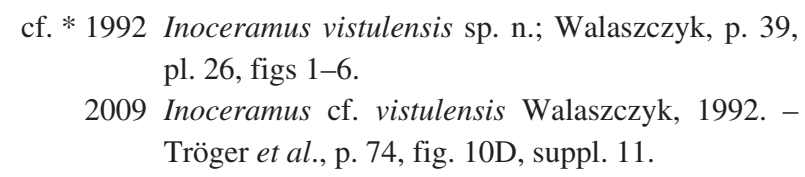

Material. - 1 double-valved specimen, Marterberg Member (MMG: BaK 42).

Remarks. - Inoceramus vistulensis Walaszczyk is known from the upper Upper Turonian Mytiloides scupini Zone to the middle Lower Coniacian of Poland and Germany (Walaszczyk 1992, 1996). The single specimen from the Marterberg Member belongs to the longitudinal-oval morph of this species and is similar to the specimen figured by Walaszczyk (1992, pl. 26, fig. 6).

\section{Mytiloides mytiloidiformis (Tröger, 1967)}

Figure 9B

* 1967 Inoceramus fiegei mytiloidiformis n. sp.; Tröger, p. 108, pl. 13, figs 16, 18, pl. 11, fig. 4.

2009 Mytiloides mytiloidiformis (Troeger, 1967). - Tröger et al., p. 83, fig. 12J, K, M, suppl. 19.

Material. - 5 specimens, Marterberg Member (MMG: BaK 96/1, 2, 97/1-3).

Remarks. - Mytiloides mytiloidiformis (Troeger) is a characteristic inoceramid bivalve of the upper Upper Turonian (Mytiloides scupini Zone) to middle Lower Coniacian of Europe, Japan and probably North America (Walaszcyk \& Szasz 1997). In the Danubian Cretaceous Group it also occurs in the Upper Turonian Großberg Formation (Tröger et al. 2009).

\section{Rhyssomytiloides? sp.}

Figure 9A

2009 Rhyssomytiloides? sp.; Tröger et al., p. 84, fig. 16, suppl. 21. 


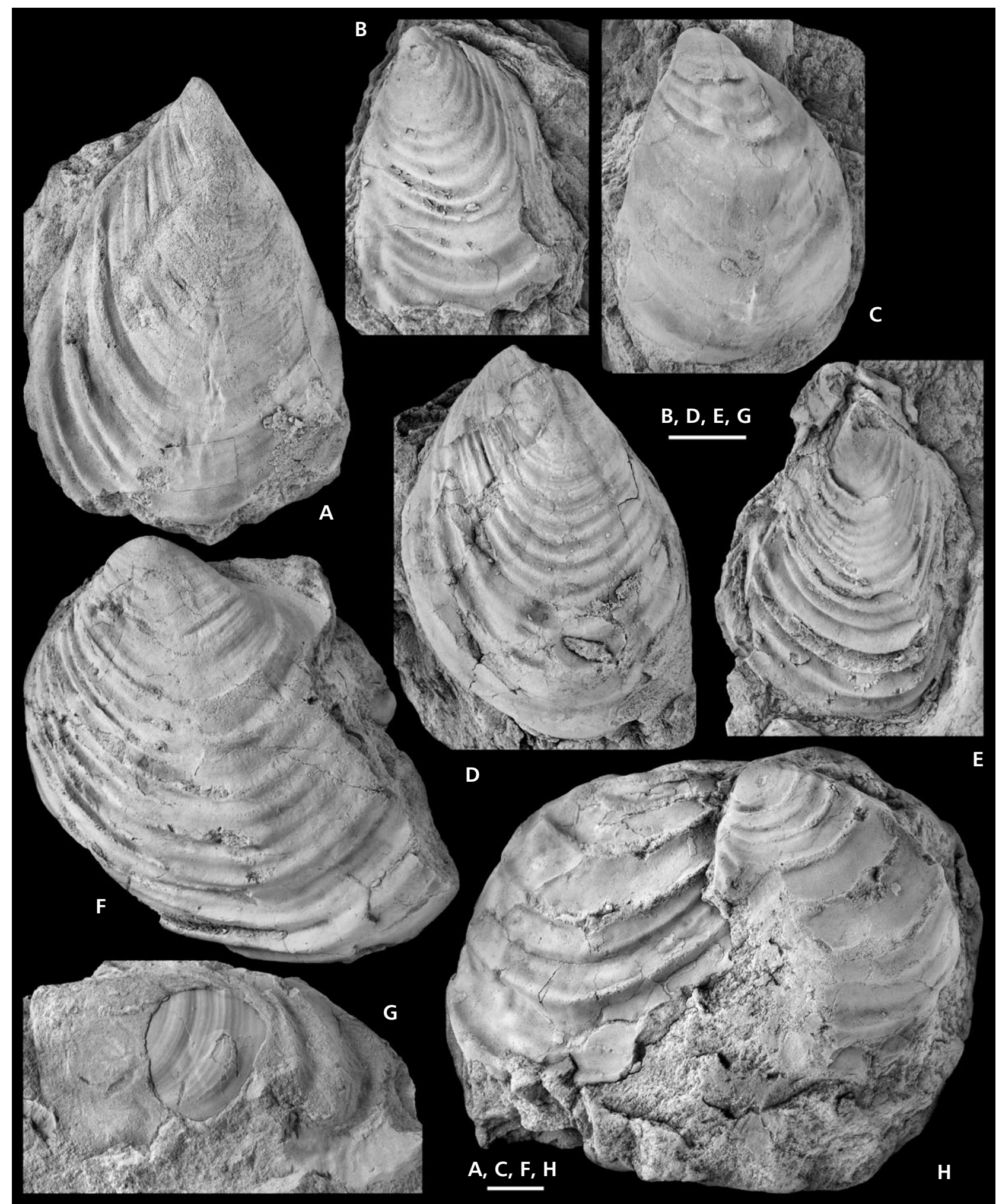

Figure 9. Bivalvia: Inoceramidae. • A - Rhyssomytiloides? sp., MMG: BaK 165. Marterberg Member. • B - Mytiloides mytiloidiformis (Tröger, 1967), MMG: BaK 97. Marterberg Member. $\bullet \mathrm{C}-$ Cremnoceramus deformis erectus (Meek, 1877), MMG: BaK 40. Buchleiten Member. $\bullet \mathrm{D}-$ Cremnoceramus rotundatus (Fiege, 1939) sensu Tröger (1967), MMG: BaK 46. Marterberg Member. $\bullet$ E - Cremnoceramus waltersdorfensis hannovrensis (Heinz, 1932), MMG: BaK 44. Marterberg Member. • F - Cremnoceramus crassus cf. cripsioides (Elbert, 1901), MMG: BaK 45. Buchleiten Member. • G - Platyceramus sp. ex gr. mantelli (de Mercey, 1872), MMG: BaK 69. Buchleiten Member. • H - Inoceramus cf. vistulensis Walaszczyk, 1992, MMG: BaK 42. Marterberg Member. Scale bars $=10 \mathrm{~mm}$. 
Material. - 1 specimen, Marterberg Member (MMG: BaK 165).

Remarks. - In Central Europe, mytiloid inoceramids occur in the Lower to basal Middle Turonian, and again in middle and upper Upper Turonian strata. Generally, the genus Rhyssomytiloides is typical of the Lower Turonian of the southern continents (Hessel 1988). Its occurrence in the Coniacian and Santonian is regarded as doubtful (Kennedy et al. 2008).

Cremnoceramus rotundatus (Fiege, 1930) sensu Tröger (1967)

Figure 9D

* 1930 Inoceramus inconstans rotundatus; Fiege, p. 42, fig. 3, pl. 7, fig. 32 [non pl. 8, figs 31, 33].

2009 Cremnoceramus rotundatus (Fiege, 1930) sensu Tröger (1967). - Tröger et al., p. 87, fig. 18D, suppl. 23.

Material. - 1 specimen, Marterberg Member (MMG: BaK 46).

Remarks. - According to Herm et al. (1979), Cremnoceramus rotundatus (Fiege) is the earliest member of the cosmopolitan rotundatus-erectus-deformis lineage. In contrast, Walaszcyk \& Wood (1998, fig. 6) recognise only one species, i.e., C. deformis, with three successive chronosubspecies, i.e., the early $C$. d. erectus (Meek), C. $d$. dobrogensis (Szasz), and the nominate subspecies, the late $C . d$. deformis (Meek). C. rotundatus (Fiege) sensu Tröger (1967) is placed in the synonymy of $C$. $d$. erectus. However, Tröger et al. (2009) again regard $C$. rotundatus as a separate species, but otherwise agree with the subdivision of $C$. deformis into two subspecies. These authors claim that $C$. rotundatus is markedly more slender than typical $C$. deformis erectus. Cremnoceramus rotundatus (Fiege) sensu Tröger (1967) [= C. deformis erectus (Meek) sensu Walaszcyk \& Wood (1998)] has its first occurrence at the base of the Coniacian, and is thus used as a marker for the Turonian-Coniacian boundary (Kauffman et al. 1996).

\section{Cremnoceramus deformis erectus (Meek, 1877) [= Cremnoceramus brongniarti (Mantell, 1822) sensu Walaszczyk (1992)]}

Figure 9C

* 1877 Inoceramus erectus $\mathrm{n}$. sp.; Meek, p. 145, pl. 13, fig. 1, 1a, pl. 14, fig. 3 .

2009 Cremnnoceramus deformis erectus (Meek, 1877). Tröger et al., p. 86, figs 17, 18A, B, suppl. 22.
Material. - 3 specimens, Buchleiten Member (MMG: BaK 40/1, 2).

Remarks. - Cremnoceramus erectus is regarded as the middle member of the rotundatus-erectus-deformis lineage by Herm et al. (1979). Walaszcyk \& Wood (1998) downgraded this form to subspecies rank, now named C. deformis erectus (Meek). According to Tröger et al. (2009) broad morphs of $C$. $d$. erectus (Meek) are typical of the middle to upper Lower Coniacian. $C$. d. erectus occurs in Europe, North America, and Japan (Walaszcyk \& Wood 1998).

\section{Cremnoceramus waltersdorfensis hannovrensis (Heinz, 1932)}

Figure 9E

* 1932 Inoceramus hannovrensis n. sp.; Heinz, p. 29.

2009 Cremnoceramus waltersdorfensis hannovrensis (Heinz, 1932). - Tröger et al., p. 88, fig. 18F, suppl. 24.

Material. - 1 specimen, Marterberg Member (MMG: $\mathrm{BaK} 44)$.

Remarks. - This subspecies represents the stratigraphically younger member of the waltersdorfensis lineage and is the index taxon of the Cremnoceramus hannovrensis Zone of the middle Early Coniacian (Walaszcyk \& Wood 1998). From C. w. waltersdorfensis (Andert), the stratigraphically oldest member and oldest representative of Euramerican cremnoceramids (Kaufmann in Herm et al. 1979), C. w. hannovrensis (Heinz) differs in its broader size and in the development of the umbonal part (Walaszcyk \& Wood 1998). Generally known from Europe and North America, this subspecies has a narrow range from the middle to upper Lower Coniacian, and predominates the Central European inoceramid assemblages of that time interval.

\section{Cremnoceramus crassus cf. cripsioides (Elbert, 1901)} Figure 9F

1901 Inoceramus crassus var. cripsioides n. var.; Elbert, p. 111.

cf. * 1913 Inoceramus crassus var. cripsioides Elbert. - Andert, p. 296, fig. 12.

2009 Cremnoceramus crassus cf. cripsioides (Elbert, 1901). - Tröger et al., p. 90, figs 18C, E, H, 20; suppl. 25.

Material. - 4 specimens, Marterberg Member and 1 specimen, Buchleiten Member (MMG: BaK 43/1, 2, 45, 95/1, 2). 
Remarks. - This form is the single one that occurs in both members of the Sandbach Formation (Tröger et al. 2009). The five specimens from the MMG collection were previously identified as Inoceramus cripsi Mantell, Sphaeroceramus aff. volgershallensis Heinz, Inoceramus cuvieri var. cripsioides Elbert, Inoceramus? cuvieri Mantell and Inoceramus? crassus Petrascheck by Hanns Bruno Geinitz and Rudolf Heinz. According to Walaszczyk \& Wood (1998) the crassus lineage first appears in the upper Lower Coniacian and possibly ranges into the basal Middle Coniacian.

\section{Platyceramus sp. ex gr. mantelli (de Mercey, 1872)} Figure 9G

* 1872 Inoceramus Mantelli n. sp.; de Mercey, p. 21.

2009 Platyceramus sp. ex gr. mantelli (de Mercey, 1872). Tröger et al., p. 91, fig. 21.

Material. - 1 specimen, Buchleiten Member (MMG: BaK 69).

Remarks. - Platyceramus sp. ex gr. mantelli (de Mercey) first occurs in the topmost Lower Coniacian and is characteristic of the Middle Coniacian of western Europe (Tröger 1974, Tröger \& Summesberger 1994). In the Danubian Cretaceous Group this taxon is also known from the Jeding Formation of the northwestern part of the Bodenwöhrer Senke near Amberg (Tröger et al. 2009, Niebuhr 2011). Moreover, several members of the mantelli group occur in sediments of the Upper Cretaceous Gosau Group (Northern Calcareous Alps, Austria; Tröger \& Summesberger 1994).

Order Ostreida Rafinesque, 1815

Family Gryphaeidae Vialov, 1936

\section{Exogyrinae indet.}

Figure 8E, G

Material. - $6 \mathrm{LV}$ and $1 \mathrm{RV}$, Buchleiten Member (MMG: BaK 75, 79).

Description. - Right valve only visible from inside; small, oval, relatively thick. Ligamental area very small, almost indistinguishable. Adductor muscle scar small, almost D-shaped in horizontal direction (Fig. 8E). Left valve inflated, incurved, slightly opisthogyrous, with broad, somewhat truncated umbo. Shell surface smooth with faint growth lines (Fig. 8G). Inner shell features unknown.

Remarks. - The specimens are relatively poorly preserved. From the general shape of the valves, however, it seems likely that both right and left valves belong to a single taxon.
The opisthogyrous shell coiling in the left valve, the shape of the adductor muscle scar, and the strongly inaequivalve shells are typical of the Exogyrinae sensu Malchus (1990). A more detailed determination is impossible.

Family Arctostreidae Vialov, 1983

\section{Rastellum diluvianum (Linnaeus, 1767)}

Figure 8B

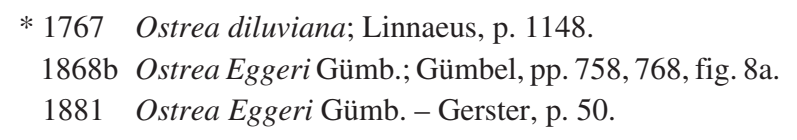

Material. - 2 specimens, Marterberg Member (MMG: $\mathrm{BaK}$ 101).

Remarks. - Both specimens are very small and preserved as internal moulds of single valves. The slender, sickleshaped outline and the imprints of the more or less regularly folded shell margin and short, straight ligament suggest a generic assignment to Rastellum. The latter feature, in particular, prevents an assignment to the similar-shaped Agerostrea, which has its first appearance in the Late Turonian to Early Coniacian (Malchus 1990). Adopting Woods' (1913) hypothesis that all Cretaceous Rastellum belong to a single species, the two specimens from the Marterberg Member are correctly named Rastellum diluvianum.

\section{Ostreida indet.}

Material. - 1 specimen, Marterberg Member.

Remarks. - A small, indeterminable, poorly preserved, thick-shelled specimen with a partly broken margin (not illustrated) is obviously different from those taxa described above. Indeterminable juvenile oysters are also found as epizoans on Hillendia bohemica (Fig. 6D, E).

Order Pectinida Gray, 1854

Family Anomiidae Rafinesque, 1815

\author{
Anomia sp. \\ Figure 8N \\ ? 1852 Anomya truncata Gein. - Stockheim, p. 90.
? 1868 b Anomia truncata Gein. - Gümbel, p. 758.
? 1881 Anomia subtruncata Gein. - Gerster, p. 18.
}

Material. - 1 specimen, Marterberg Member (MMG: BaK 63). 
Remarks. - The single free valve lacks the umbo; it is sub-circular in outline and relatively globose. Its surface is smooth with irregular growth lines, and faint arcuate pseudo-sculpture in the ventral shell part. Determination at species level is impossible.

\section{Family Pectinidae Rafinesque, 1815}

Remarks. - The pectinids from the Stockheim collection were studied, determined, and labelled by Annie V. Dhondt $(\dagger)$ in 1967, and the specimens are mentioned in the material sections of her publications (Dhondt 1972a, b, 1973). After having checked all relevant details, the identifications of A. Dhondt were adopted for the present paper.

\section{Lyropecten (Aequipecten?) ternatus (Münster in Goldfuss, 1833)}

Figure 8L

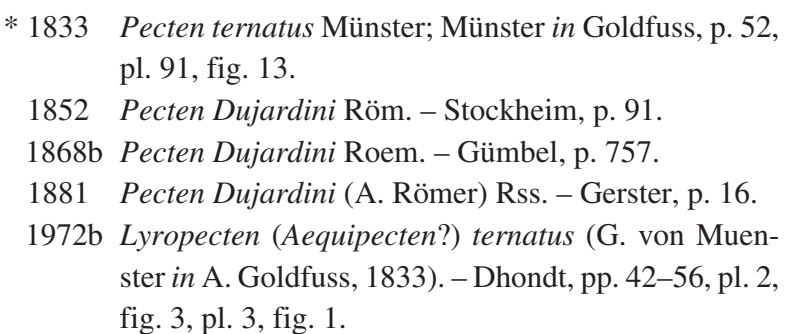
For extensive synonymy see Dhondt (1972b).

Material. - 1 specimen, Marterberg Member (MMG: $\mathrm{BaK}$ 100).

Remarks. - The specimen shows part of the ventral portion of a left valve, including six primary ribs. In three of those, the typical ornamentation consisting of two secondary ribs on each side of the primary ribs, and two additional secondary ribs in the primary interspaces (Dhondt 1972b), is still discernable.

\section{Camptonectes (Camptonectes) virgatus}

\section{(S. Nilsson, 1827)}

Figure 8F, H

\footnotetext{
* 1827 Pecten virgatus n.; Nilsson, p. 22, pl. 9, fig. 14.

1868 b Pecten virgatus Nils. - Gümbel, p. 756.

1881 Pecten virgatus Nilss. - Gerster, p. 49.

1972a Camptonectes (Camptonectes) virgatus (S. Nilsson, 1827). - Dhondt, pp. 18-33, pl. 2, fig. 1.
}

For extensive synonymy see Dhondt (1972a).

Material. - 3 specimens, Marterberg Member (MMG: BaK 108/1, 2).
Remarks. - All specimens bear remnants of shell showing the typical Camptonectes-type micro-ornamentation. In one specimen (Fig. $8 \mathrm{H}$ ), the general, orbicular outline of the shell including faint imprints of the auricles is visible. In a second specimen (Fig. 8F), the typical, wing-like, elongated anterior auricle of a right valve (Dhondt 1972a) is preserved.

Family Neitheidae Sobetski, 1960

Neithea (Neithea) quinquecostata (J. Sowerby, 1814) Figure 8M

* 1814 Pecten quinquecostata; J. Sowerby, pp. 122, 123, pl. 56, figs 4-8.

1852 Pecten quinquecostatus Sow. - Stockheim, p. 88.

? 1852 Pecten quadricostatus Sow. - Stockheim, p. 91.

1881 Janira quinquecostata d'Orb. - Gerster: 17, 18.

1973 Neithea (Neithea) quinquecostata (J. Sowerby, 1814). - Dhondt, pp. 29-37, pl. 2, fig. 2.

For extensive synonymy see Dhondt (1973).

Material. - 3 specimens, Marterberg Member and 1 specimen, Buchleiten Member (MMG: BaK 64, 67).

Description. - Only right valves preserved. Small to medium sized, moderately incurved, orthogyrous shell with six prominent, sharp primary ribs and three to four sharp, regular intercalary secondary ribs. Auricles not visible. Growth lines indistinct to invisible.

Remarks. - The characteristic ribbing pattern of this species is clearly seen in at least two specimens from the Sandbach Formation.

Order Limida Moore, 1952

Family Limidae Rafinesque, 1815

\section{Lima multicostata Geinitz, 1839}

Figure 8I

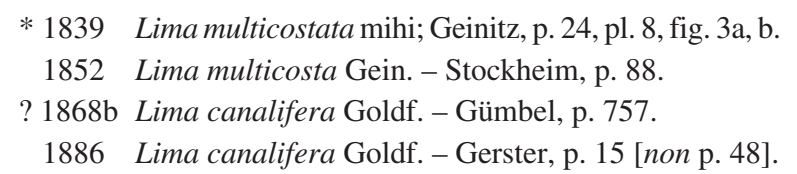

Material. - $1 \mathrm{RV}$ internal mould with remnants of shell, Buchleiten Member (MMG: BaK 76).

Description. - Shell large ( $\mathrm{H}>70 \mathrm{~mm})$, oblique-oval, only slightly inflated. Anterior margin straight, bending into well rounded ventral and posterior margins. Anterior auricle not preserved; posterior auricle relatively large and 
distinct, with bluntly angled corner, slightly rolled up, ornamented with irregular growth lines. Shell disc ornamented with almost 30 regularly spaced, relatively sharp radial costae with broad interspaces.

Remarks. - The authors do not agree with Woods (1904) and other scholars, who placed Lima multicostata in the synonymy of $L$. canalifera Goldfuss. As clearly stated by Woods (1904), the latter species usually has 18 (14 to 21) radial costae on the disc surface, while L. multicostata as figured by Reuss (1846) or Geinitz (1850) has almost 30 radial costae. The same observations were already made by Gerster (1881), who distinguished both species among his obviously numerous specimens, based on the significant difference in rib numbers. However, either accidentally or deliberately, Gerster (1881) did not list the species with its correct name.

\section{Lima pseudocardium? Reuss, 1846}

Figure 8C

?*1846 Lima pseudocardium Reuss; Reuss, p. 33, pl. 38, figs 2,3 .

? 1852 Lima pseudocardium Reuss. - Stockheim, p. 86.

Material. - 1 fragmentary RV, Buchleiten Member (MMG: BaK 87).

Description. - Mould of a shell fragment, comprising approximately two-thirds of total size. Shell high-oval (?), ornamented with numerous slender, prominent ribs that are rounded on top; rib interspaces twice as broad as ribs, flat and smooth.

Remarks. - The inflation of the fragment and inclination of the ribs closely resemble those parameters often observed in small Limidae (e.g., Pseudolimea, Limea). Lima pseudocardium, described by Reuss (1846) from several Cretaceous strata of Bohemia, compares well with regard to the pattern and style of the ribs, and it seems appropriate to assign the specimen from the Buchleiten Member to this species. However, as hinge details are lacking, both the generic and specific assignment are provisional.

Superoder Heteroconchia Gray, 1854

Clade Heterodonta Neumayr, 1884

Order Carditida Dall, 1889

Family Carditidae Férussac, 1822

Cyclocardia? sp.

Figure 10E

Material. - 1 internal mould, Buchleiten Member (MMG: BaK 57).
Description. - Shell roundish, slightly higher than long, moderately inflated and slightly prosogyrous. Approximately 20 well rounded radial ribs covering entire shell surface.

Remarks. - This poorly preserved specimen resembles the Cardiidae described below with regard to rib number. However, the shell seems to be somewhat more rounded, lacks anterior- and posterior-dorsal corners, and the ribs are less sharp than in the Cardiidae. Thus, the specimen is tentatively placed within the genus $C y c$ locardia.

Order Venerida Gray, 1854

Family Arcticidae Newton, 1891

\section{Venilicardia? sp.}

Figure 10M

Material. - 2 specimens with contiguous valves, Marterberg Member (MMG: BaK 49).

Remarks. - Both specimens are distorted, poorly preserved internal moulds lacking information about shell surface and hinge characters. The large size, strong inflation and strongly incurved umbones are characters generally occurring in only a few bivalve taxa. In the Cretaceous, these are usually members of the genus Venilicardia. Any determination, however, is impossible due to the poor preservation of the specimens.

Family Cardiidae Lamarck, 1809

\section{Laevicardium? sp.}

Figure 10L

Material. - 2 specimens, Marterberg Member (MMG: BaK 55).

Description. - Shell oblique, short-oval, strongly inflated, with well-rounded margin and slightly extended postero-ventral shell portion. Umbones prominent, orthogyrous, central, moderately blunt. Shell surface covered with numerous fine radial ribs with extremely narrow interspaces. Hinge characters unknown.

Remarks. - Both outline and ornamentation of the specimens perfectly match those features seen in Laevicardium. However, so far, this genus has been recorded exclusively from Cenozoic strata, and the lack of hinge characters prevents a definitive assignment. 


\section{Cardiidae indet. 1}

Figure 10A, C, D, F, G

1852 Cardium Ottonis Gein. - Stockheim, p. 92.

1868b Cardium Ottoi Gein. - Gümbel, pp. 754, 765, fig. 3.

1868b Cardium Eggeri Gümb.; Gümbel, pp. 755, 765, fig. 4.

1881 Cardium Ottoi (Gein.) Gümb. - Gerster, p. 42.

1881 Cardium Eggeri Gümb. - Gerster, p. 42.

Material. - Ca 40 specimens, several of them in butterfly position, all Marterberg Member (MMG: BaK $50 / 1,2,58)$.

Description. - Small cardiids with roundish to slightly oblique shell outline; moderately inflated. Umbo relatively narrow, slightly prosogyrous. Shell ornamented with approximately 25 relatively narrow, slightly rounded radial ribs. Interspaces slightly broader than ribs. Internal shell features not preserved.

Remarks. - Due to the lack of internal shell features, the shells cannot be assigned at genus or species level. Cardium ottonis Geinitz listed by Stockheim (1852), Gümbel (1868b, p. 765, fig. 4), and Gerster (1881) and Cardium eggeri (Gümbel, 1868b) are of similar size and have similar rib numbers (25-30; Geinitz 1850, Gümbel 1868b), but differ slightly in outline and in the thickness of the radial ribs. It seems dubious that these are really two distinct species both occurring at Marterberg; the differences seem rather to result from poor preservation and distortion. With regard to their general appearance the specimens resemble modern Cerastoderma. This is the most common bivalve species of the Marterberg Member.

\section{Cardiidae indet. 2}

Figure 10G (white arrows)

Material. - 2 specimens and 2 external moulds, Marterberg Member (MMG: BaK 58).

Remarks. - Small, relatively globose cardiids with numerous fine radial ribs that may belong to a single or two different species; indeterminable due to poor preservation.

Family Tellinidae Blainville, 1814

\section{Linearia subdecussata (Roemer, 1841)}

Figure 10A, B

* 1841 Tellina subdecussata N.; Roemer, p. 75; pl. 9, fig. 20.

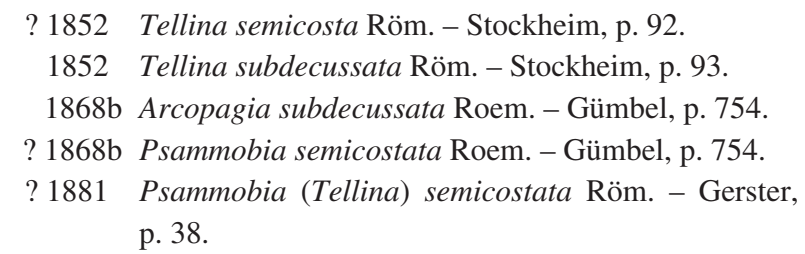

Material. - 1 specimen, Buchleiten Member, 1 specimen, Marterberg Member (MMG: BaK 45, 53).

Description. - Shell elongate-oval, relatively flat, with well-rounded anterior and posterior margins. Ventral margin only slightly rounded. Anterior- and posteriordorsal margins straight. Umbo elevated, triangular, almost pointed; positioned at about anterior third of shell length. Shell ornamented with numerous regular sharp commarginal ribs that are crossed by several evenly sharp radial costae on the anterior shell portion, and several less distinct costae in the posterior shell portion. Only indistinct radial lines in early growth stages of central shell portion.

Remarks. - One of the two specimens from the Sandbach Formation, i.e., the one from the Buchleiten Member (Fig. 10A), is well preserved and undistorted. It clearly shows a non-central, pointed umbo and relatively straight anterior- and posterior-dorsal shell margins, and thus closely resembles Linearia subdecussata (Roemer, 1841). In the second, slightly distorted specimen from the Marterberg Member (Fig. 10B) these features are less distinct, and it could well be attributed to $L$. semicostata (Roemer, 1841) or L. subtenuistriata (d'Orbigny, 1850). However, it seems doubtful that these three species are distinct.

Tellinidae? indet.

Figure 10G (black arrow), H

Material. - 2 specimens, Marterberg Member (MMG: BaK 52, 58).

Description. - Shell short oval, relatively flat, thin; posterior end somewhat narrower than anterior end. Umbo more or less orthogyrous, positioned almost centrally. Shell surface covered with numerous fine but distinct regular growth lines. Internal shell features unknown.

Remarks. - The thin shell that is partly preserved in one specimen, the flatness, and the oval shell shape may indicate a position in the Tellinidae. However, taxonomic assignment is impossible in the absence of the internal shell characters. 

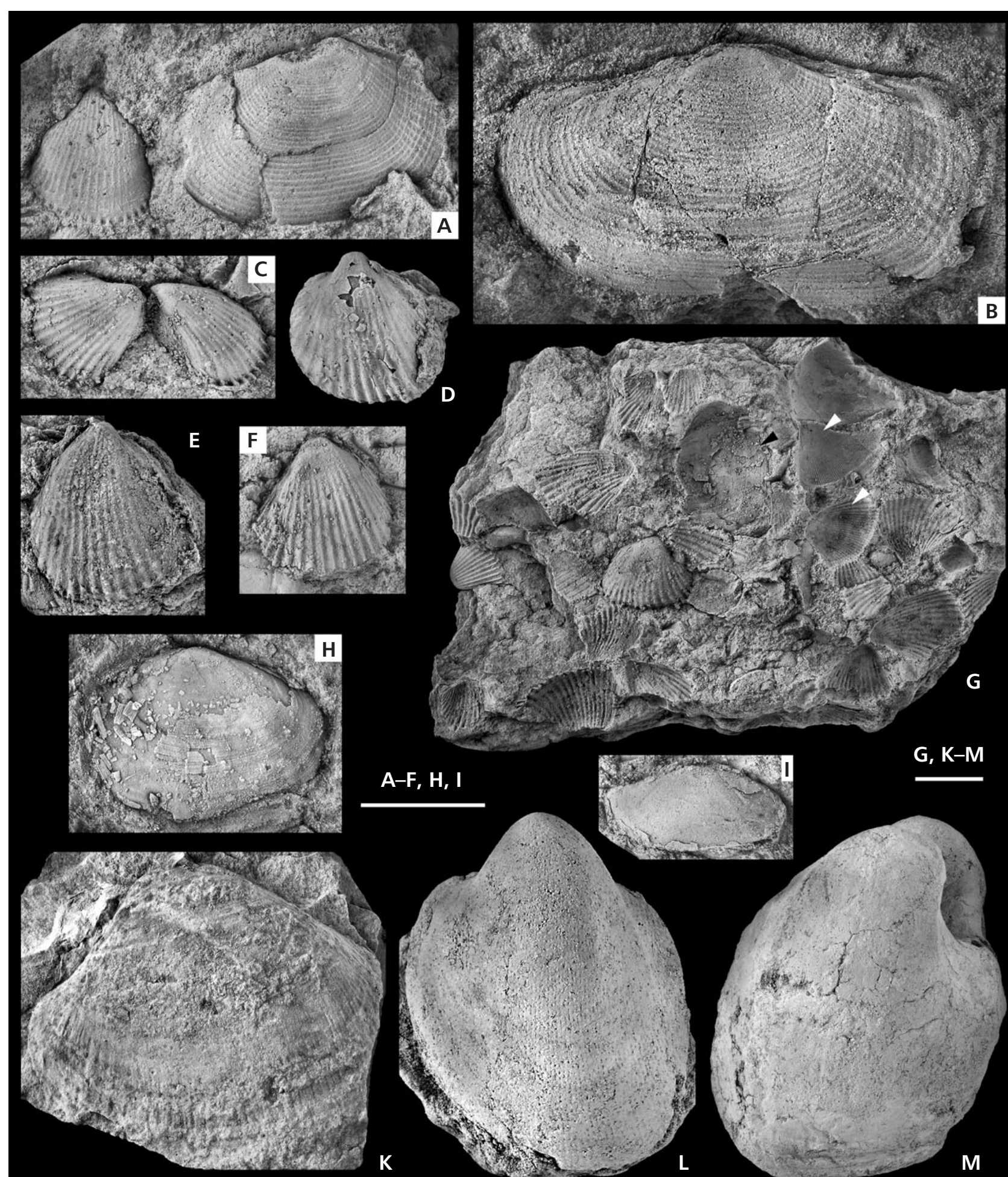

\section{(1)}

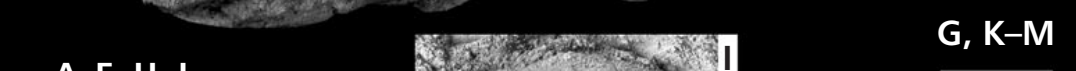

Figure 10. Bivalvia: Heteroconchia. • A - Linearia subdecussata (Roemer, 1841) (right) and Cardiidae indet. 1 (left). MMG: BaK 53. Marterberg Member. • B - Linearia subdecussata (Roemer, 1841), MMG: BaK 45. Buchleiten Member. $\bullet$, D, F - Cardiidae indet. 1. MMG: BaK 50/1, 50/2, 58. Marterberg Member. $\bullet$ E-Cyclocardia? sp., MMG: BaK 57. Buchleiten Member. $\bullet \mathrm{G}-$ Cardiidae indet. 1 - Cardiidae indet, 2 (white arrows), Tellinidae? indet. (black arrow). MMG: BaK 58. Marterberg Member. $\bullet$ H - Tellinidae? indet., MMG: BaK 52. Marterberg Member. $\bullet$ I-Tancredia? sp., MMG: BaK 102. Marterberg Member. $\bullet$ K - Heterodonta indet. 1, MMG: BaK 68. Buchleiten Member. $\bullet$ - Laevicardium? sp., MMG: BaK 55. Marterberg Member. - M - Venilicardia? sp., MMG: BaK 49. Marterberg Member. Scale bars $=10 \mathrm{~mm}$. 
Family Tancrediidae? Meek, 1864

\section{Tancredia? sp.}

Figure 10I

Material. - 1 specimen, Marterberg Member (MMG: BaK 102).

Description. - Small, elongate shell with roundly pointed anterior shell end. Anterior-dorsal margin slightly concave. Umbo indistinct, slightly prosogyrous. Blunt but distinct radial ridge running from umbo towards posteriorventral shell corner. Internal shell features unknown.

Remarks. - Without knowledge of internal shell characters a definitive determination is impossible. However, the general shell characters, especially the incurved anteriordorsal margin and the posterior radial ridge, closely resemble those seen in the genus Tancredia.

\section{Heterodonta indet. 1}

Figure 10K

Material. - 1 specimen, Buchleiten Member (MMG: BaK 68).

Remarks. - Large sub-trigonal specimen with remnants of shell, showing numerous radial pseudo-ribs that occur in the inner shell layers, as commonly seen, e.g., in Glycymeris or several cardiids. Internal shell features are unknown and thus this form remains indeterminable.

\section{Heterodonta indet. 2}

Material. - 1 specimen, Buchleiten Member (MMG: BaK 74).

Remarks. - The poorly preserved mould of a $>40 \mathrm{~mm}$ long, moderately inflated, slightly prosogyrous bivalve shows no details of hinge or ornamentation. The specimen is definitely distinct from the previously described taxa, albeit indeterminable.

Order Pholadomyida Newell, 1965

Family Laternulidae Hedley, 1918

\section{Cercomya lanceolata (Geinitz, 1843)}

* 1843 Corbula lanceolata m.; Geinitz, p. 12, pl. 2, fig. 3.

1901 Anatina lanceolata Gein. - Sturm, pp. 87, 88, pl. 8, fig. 10.

Material. - 1 specimen, Marterberg Member (BSPG 2002 XIII 367).
Remarks. - The composite mould shows the typical rostrate posterior end, irregular commarginal ornamentation and posterior carina that characterise this species.

Class Gastropoda Cuvier, 1795

Clade Sorbeoconcha Ponder \& Lindberg, 1997

Family Turritellidae Lovén, 1847

\section{Turritella sp.}

Figure 11G

Material. - 8 specimens, Marterberg Member (MMG: BaK 10, 12) BSPG 2002 XIII 381).

Remarks. - The specimens from the Stockheim collection are poorly preserved internal moulds with the external ornament weakly imprinted. Several boulders collected by the first author in a little creek near Mahd (see Fig. 1: 6), yielded three external moulds of Turritella sp., one of which was sufficiently well preserved to take a rubber cast of at least five whorls. It represents a species with a relatively large apical angle, strongly angular whorl cross-section, and an ornament of six distinct spiral bands, with the fifth band significantly more prominent than the others; the shell was drilled by a carnivorous gastropod. The cast from Mahd closely resembles T. subalternans Briart \& Cornet as illustrated by Geinitz (1871-1875), which is, however, significantly different from the specimen depicted by Briart \& Cornet (1870). The latter is much more steeply inclined and shows only three spiral bands. The poorly preserved specimens from the Stockheim collection are similar to the moulds collected at Mahd with regard to their general proportions, but might prove eventually to represent a different species. In the light of these difficulties, the species is left in open nomenclature.

Clade Hypsogastropoda Ponder \& Lindberg, 1997

Subclade Littorinimorpha Golikov \& Starobogatov, 1975

Family Aporrhaidae Gray, 1850

\section{"Aporrhais" anserina (Nilsson, 1827)}

Figure 11B

\footnotetext{
* 1827 Rostellaria anserina, n.; Nilsson, p. 13, pl. 3, fig. 6.

1841 Rostellaria vespertilio; Goldfuss, p. 17, pl. 170, fig. 5.

1846 Rostellaria anserina Nilsson. - Reuss, p. 111, pl. 45, fig. 19.

1852 Rostellaria vespertilio Gf. - Stockheim, p. 93.

1868b Rostellaria vespertilio Goldf. - Gümbel, p. 753.

1850 Rostellaria anserina Nilss. - Geinitz, p. 9, pl. 1, fig. 10.

1881 Alaria vespertilio Goldf. sp. - Gerster, p. 32.
} 


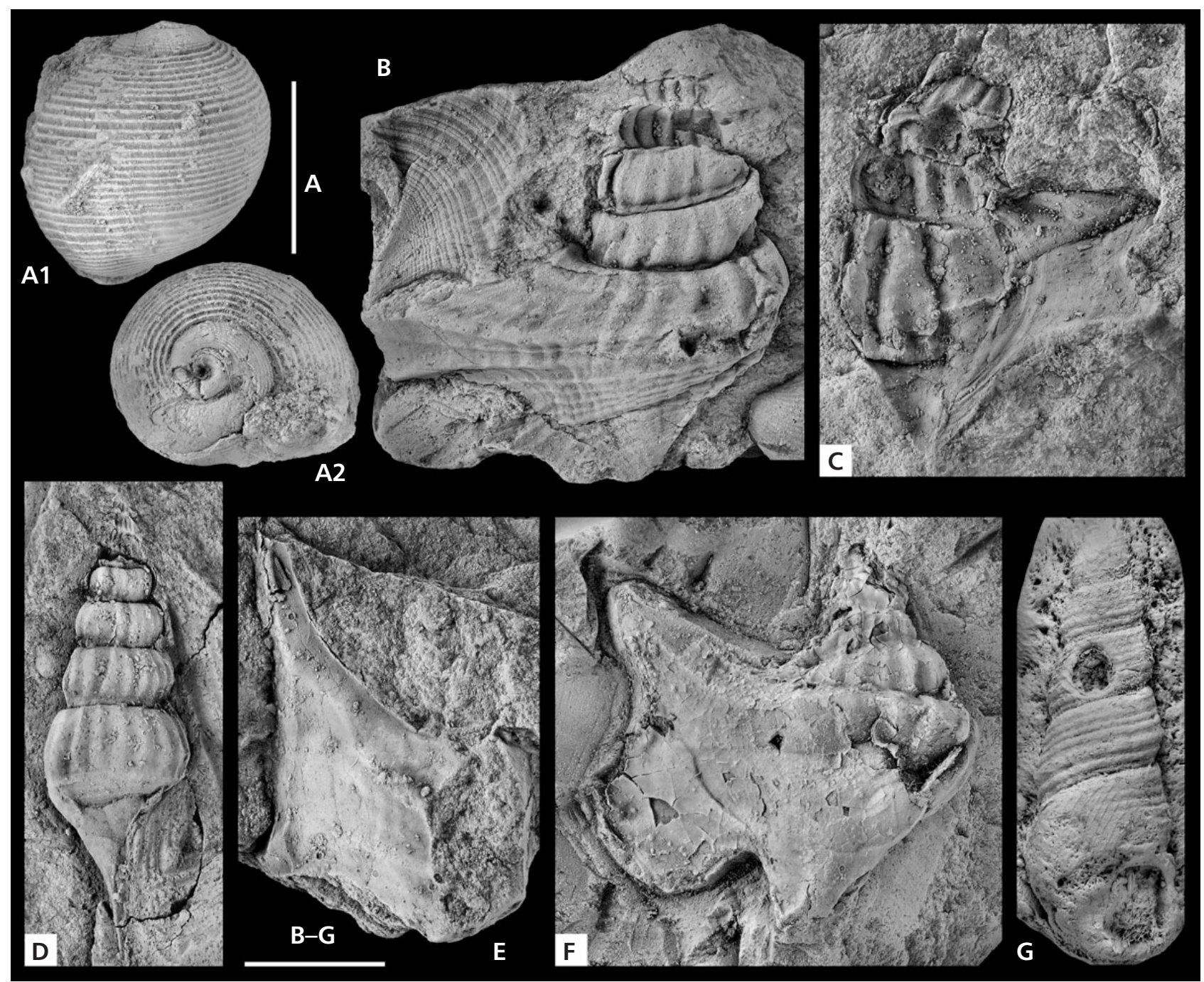

Figure 11. Gastropoda. • A - Avellana cf. humboldti, J. Müller, 1851, MMG: BaK 18. Marterberg Member. • B - “Aporrhais" anserina (Nilsson, 1827), MMG: BaK 17. Marterberg Member. • C, F - Perissoptera megaloptera Reuss, 1844, MMG: BaK 14/1, 16/1. Marterberg Member. •D - Aporrhaidae indet., MMG: BaK 16/2. Marterberg Member. • E - Latiala cf. tenuistriata (Reuss, 1844), MMG: BaK 14/2. Marterberg Member. • G - Turritella sp., rubber cast, BSPG 2002 XIII 381. Marterberg Member, Mahd N Untervoglarn. Scale bars $=10 \mathrm{~mm}$.

1901 Aporrhais hirundo nov. spec.; Sturm, p. 68, pl. 5, fig. 3.

Material. - 1 partial composite mould, Marterberg Member (MMG: BaK 17).

Description. - Specimen preserved on matrix, abapertural view. Four whorls of spire preserved, the earlier two as external mould, the later ones as composite mould; spire relatively low-turriculate. Whorls more or less constantly rounded, with faint, rounded shoulder and marked constriction directly above the suture. Eight moderately opisthocline radial ribs visible on each whorl (consequently, there are 15 or 16 ribs per whorl in total). Delicate ornamentation of numerous fine spiral lines visible on external mould of earliest whorls. Last whorl broadened, almost as high as spire; ornamented with strongly curved collabral ribs and two minor spiral bands in slightly concave adapical portion; central part marked by two strong, elevated spiral bands with groove and one minor spiral band in between; abapical portion of last whorl slightly concave, ornamented with eight minor spiral bands and several weak radial ribs. Proximal digitation short, rounded, not attached. Labral wing not fully preserved; central portion of last whorl extends in a broad horizontal band with two ridges that end in more or less acute corners; abapical portion of wing broadens slightly to form fan-shaped extension.

Remarks. - The specimen from the Marterberg Menber closely resembles specimens figured by Reuss (1846), Geinitz (1850), and Sturm (1901). Obviously, none of these scholars had seen the type material of Nilsson (1827), 
which seems to be relatively poorly preserved. Moreover, it is likely that the drawing of the shell partly represents a (possibly erroneous) reconstruction. Consequently, Sturm's (1901) decision to erect a new species, Aporrhais hirundo, appears rather arbitrary. Herein the species name anserina Nilsson is provisionally retained for the specimens from Bohemia, Saxony, Poland, and southern Germany, pending an examination of the type material from Sweden. Although the ornamentation of the species is close to that of Aporrhais, the shape of the labral wing differs from the relatively simple arrangement of finger-like extensions seen in the latter genus. As no other appropriate genus name is available for anserina Nilsson, and any taxonomic decisions should be based on the type material of the species, we refrain from erecting a new genus.

\section{Latiala cf. tenuistriata (Reuss, 1844)} Figure 11E

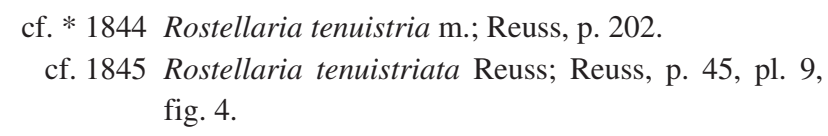
fig. 4 .

Material. - 1 internal mould of labral wing, Marterberg Member (MMG: BaK 14/2).

Description. - Labral wing relatively large, almost rhomb-shaped, with external border almost parallel to spire; adapical part of wing strongly extended, spine-like, with constantly incurved adapical margin; abapical margin also incurved ("abapical notch"), but abapical corner only slightly developed, rounded. Spire and rostrum not preserved.

Remarks. - The specimen figured as Rostellaria tenuistriata by Reuss (1845) is relatively similar to the mould from the Marterberg Member. However, the dorsal spine is bent slightly more outwards in Reuss's (1845) specimen, while it is almost straight in the present specimen. As the internal mould does not show the sculpture of the labral wing, comparison is difficult. Judging from the description of the species by Reuss $(1844,1845)$ and from the shape of the labral wing described herein, an assignment to Latiala Sohl, 1960 seems indicated.

Taxonomy: The description of Rostellaria tenuistria Reuss, 1844 is valid, because the specific epithet is a correct Latin word, meaning 'narrow stripe'. However, as the epithet "tenuistriata", published by Reuss (1845), more precisely describes the morphology (tenuistriata = narrowly banded, narrowly striped) and the original, less precise spelling was cited as a senior synonym by Reuss (1845), tenuistriata may be regarded a justified emendation. Moreover, tenuistriata Reuss, 1845 has been widely used in the literature since then. Therefore, the name Latiala tenuistriata (Reuss, 1844) is considered valid herein.

Perissoptera megaloptera (Reuss, 1844)

Figure 11C, F

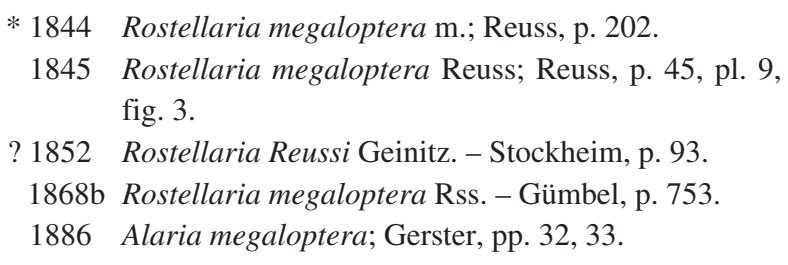

Material. - 1 composite mould and 1 external mould, Marterberg Member (MMG: BaK 14/1, 16/1).

Description. - Both specimens preserved from abapertural view. Up to five whorls of spire preserved; spire relatively low-turriculate, broad. Whorls more or less constantly rounded without marked shoulder or constrictions; six almost vertical radial ribs visible on each whorl (consequently, 12 or 13 ribs per whorl in total). Last whorl large, slightly higher than spire, with prominent shoulder shortly below the suture; collabral ribs visible only on adapical part of last whorl. Labral wing broader than spire; extended into two lobes; adapical margin almost straight; external margin markedly incurved; abapical margin S-shaped. Adapical lobe slightly tapering but blunt; faint keel running from shoulder of last whorl towards end of adapical lobe; abapical lobe rounded. Rostrum short, triangular, and tapering.

Remarks. - Perissoptera megaloptera obviously was relatively common in suitable facies of Cretaceous strata in central Europe. It is characterised by a distinctly bilobate labral wing, with the two lobes rather variable in shape and proportions. The relatively small wing seen in the external mould from the Marterberg Member (Fig. 11C) may characterise a sub-adult individual.

\section{Aporrhaidae indet.} Figure 11D

Material. - 1 composite mould, Marterberg Member (MMG: BaK 16/2).

Description. - Spire high-turriculate (apical angle $<20^{\circ}$ ); whorls rounded, with faint shoulder directly below suture, ornamented with smooth, relatively slender collabral ribs. Aperture narrow, oblique lenticular. Rostrum delicate and sharp but broken. Labral wing not preserved. 
Remarks. - The lack of the labral wing makes any generic or specific determination of this specimen impossible. However, the highly-turriculate spire, delicate rostrum and regular ornamentation with slender collabral ribs indicate that it represents a species distinct from the previously described taxa.

Clade Heterobranchia J.E. Gray, 1840

Family Ringiculidae Philippi, 1853

\section{Avellana cf. humboldti J. Müller, 1851}

Figure 11A

cf. * 1851 Avellana Humboldti Müller; J. Müller, pp. 12, 13, pl. 3 , fig. 15 .

1881 Avellana aff. Humboldti Müller. - Gerster, p. 37.

Material. - 4 specimens, 3 of them internal moulds with minor remnants of shell, Marterberg Member (MMG: BaK $18,20 / 1-3)$.

Description. - Shell almost equally high and wide, more or less round. Spire extremely low ( $<15 \%$ of total height); suture relatively deep and pronounced. Last whorl wide, globose, ornamented with 35 almost equally spaced, narrow but blunt spiral ridges; interspaces densely ornamented with fine but distinct, equally spaced, prosocline riblets that coalesce with but do not cross the spiral ridges. Details of aperture unknown.

Remarks. - Those specimens of Avellana reported from the Saxonian, Bohemian, or Polish Cretaceous, i.e., A. cassis d'Orbigny and $A$. archiaciana d'Orbigny, are referred to another genus (archiaciana) or synonymised with Avellana avellana (cassis) by Kollmann (2005). The latter, as all other globular Avellana the present authors are aware of, has significantly fewer spiral ridges (usually approximately 25) than the specimen from the Sandbach Formation. The drawing of the type of A. humboldti J. Müller, 1851 from the Early Campanian Vaals Formation of the Aachen area (Müller 1851) shows > 30 spiral ridges, but the shell is significantly less globular than in the specimen from the Sandbach Formation. Moreover, the characteristic micro-ornamentation is neither figured nor described by Müller (1851). Without having seen material from the Aachen region, which is stratigraphically distinctly younger than the specimens from Marterberg, the specific assignment remains doubtful.

\section{Gastropoda indet.}

Material. - 2 specimens, Marterberg Member.
Remarks. - Two incomplete internal moulds of small gastropods are definitely different from those taxa described above, but indeterminable.

Class Cephalopoda Cuvier, 1797

Order Nautilida Agassiz, 1847

Family Nautilidae de Blainville, 1825

Eutrephoceras sp.

Figure 12D

Material. - 1 specimen, Buchleiten Member (MMG: BaK 86).

Description. - A fully septate fragment (half a whorl) of an involute nautiloid with a diameter of $73 \mathrm{~mm}$ and a maximum whorl breadth of $50 \mathrm{~mm}$. The whorl section is depressed, the width apparently increasing rapidly during ontogeny. The sutures are simple. Shell ornament cannot be recognised.

Remarks. - Due to the poor preservation, a specific assignment is not possible and the specimen is kept in open nomenclature. The placement in the genus Eutrephoceras is based on the simple nature of the sutures and the absence of shell ornament.

Order Ammonoidea Zittel, 1884

Abbreviations. $-\mathrm{D}=$ diameter; $\mathrm{Wh}=$ whorl height; $\mathrm{Wb}=$ whorl breadth (all values in $\mathrm{mm}$ ); $\mathrm{U}=$ diameter of umbilicus as a percentage of diameter.

Family Collignoniceratidae Wright \& Wright, 1951

Peroniceras (Peroniceras) westphalicum (von Strombeck, 1859)

Figure 12C

* 1859 Ammonites westphalicus; von Strombeck, p. 56.

1984 Peroniceras (Peroniceras) westphalicum (Von Strombeck, 1859). - Kennedy, p. 71, pl. 14, fig. 5, pl. 15, figs $1-3,6,7$. [with synonymy]

1984 Peroniceras (Peroniceras) westphalicum (Von Strombeck, 1859). - Klinger \& Kennedy, p. 164, figs 24-28.

1994 Peroniceras (Peroniceras) westphalicum (von Strombeck, 1859). - Kaplan \& Kennedy, p. 48, pl. 20, figs $1,4,5,7$; pl. 21, figs 2, 3, 6; pl. 22, fig. 1; pl. 26; pl. 27; figs 1, 3-5; pl. 43, figs 1, 2.

2000 Peroniceras (Peroniceras) westphalicum Strombeck, 1859. - Wiese, p. 135, pl. 3, fig. 2. 


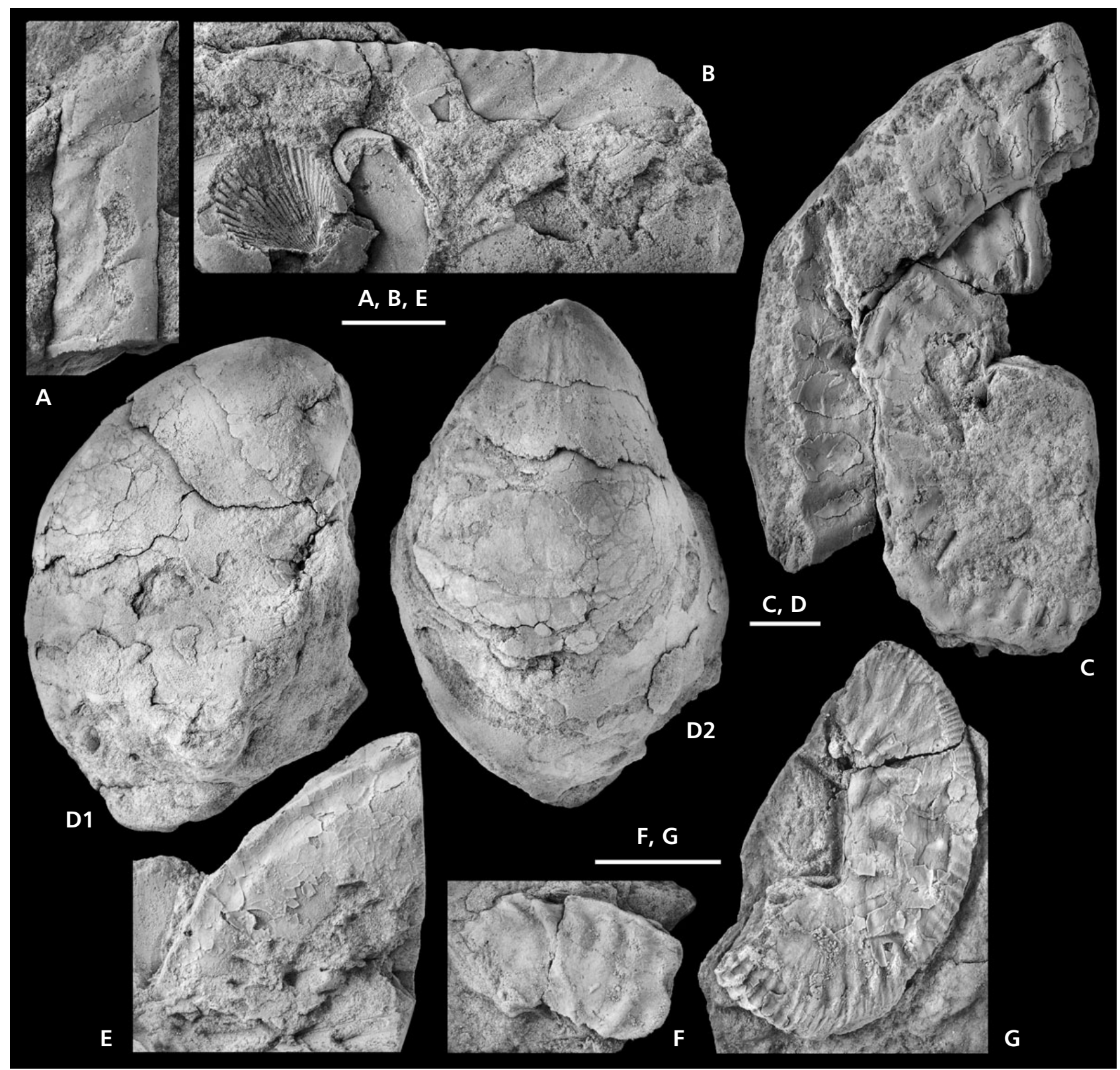

Figure 12. Cephalopoda. • A, B - Baculites sp.; A - MMG: BaK 3. Marterberg Member, B - MMG: BaK 4. Marterberg Member. $\bullet \mathrm{C}-$ Peroniceras (Peroniceras) westphalicum (von Strombeck, 1859), MMG: BaK 6/1. Buchleiten Member. • D - Eutrephoceras sp., MMG: BaK 86. Buchleiten Member. - E - Metatissotia? sp., MMG: BaK 7. Buchleiten Member. • F - Collignoniceratidae indet., MMG: BaK 8. Marterberg Member. • G - Scaphites kieslingswaldensis doylei? Wright, 1979, MMG: BaK 9. Marterberg Member. Scale bars $=10 \mathrm{~mm}$.

2009 Peroniceras (Peroniceras) westphalicum (Strombeck, 1859). - Wilmsen et al., p. 121, fig. 10B-D, F.

Material. -4 specimens, Buchleiten Member (MMG: BaK $5 / 1,2,6 / 1,2)$.

Description. - Very evolute ammonite with serpenticone coiling and compressed, rectangular whorl section (specimen $\mathrm{BaK} 6 / 1: \mathrm{D}=90 \mathrm{~mm}, \mathrm{Wh}=20 \mathrm{~mm}, \mathrm{~Wb}=11 \mathrm{~mm}, \mathrm{U}=60 \%$ ). Inner whorls are not preserved. Relatively dense, mostly sim- ple and straight prorsiradiate ribs predominate that strengthen into, and end at, clavate tubercles at the ventrolateral shoulder. Umbilical bullae are only weakly developed or absent. The keel is strong but not very high, with a smooth, shallow sulcus to each side. The lateral keels are low.

Remarks. - Gerster (1881) mentioned Ammonites tricarinatus d'Orb. [= Peroniceras (Peroniceras) subtricarinatum (d'Orbigny)] from the Buchleiten Member. The material from that member in the MMG (Stockheim collection) 
yielded several fragmentary specimens of $P$. (Peroniceras). However, we prefer to include these specimens in $P$. (P.) westphalicum (von Strombeck, 1859), based on their generally compressed whorl section, low umbilical walls, the predominance of relatively straight, slightly prorsiradiate single ribs without umbilical bullae on the outer whorls ending in moderately clavate ventrolateral tubercles, and the more-or-less monocarinate venter (see Klinger \& Kennedy 1984). P. (P.) subtricarinatum has many more rib bifurcations and a conspicuously tricarinate venter. In P. (P.) tridorsatum (Schlüter), simple ribs predominate as in our specimens, but this species is also markedly tricarinate. $P$. (P.) dravidicum (Kossmat) is similar in terms of coiling and ribbing pattern and can be very reminiscent of $P$. (P.) westphalicum.

$P$. (P.) westphalicum was regarded as a Middle Coniacian species $[P$. (P.) tridorsatum Zone; Kennedy 1984, Klinger \& Kennedy 1984]. However, subsequently this zone has been placed in the upper Lower Coniacian (Kaplan \& Kennedy 1996, Kaplan 2000), and also Wiese (2000) favoured a late Early to early Mid-Coniacian age for the species. In Westphalia, $P$. (P.) westphalicum enters in the late Early Coniacian $P$. $(P$.) tridorsatum/Cremnoceramus deformis Zone and ranges into the Middle Coniacian (Gauthiericeras margae/Volviceramus Zone; Kaplan \& Kennedy 1994, 1996).

\section{Collignoniceratidae indet.}

Figure 12F

2009 Subprionocyclus sp.; Wilmsen et al., p. 121, fig. 10A.

Material. - 1 specimen, Marterberg Member (MMG: $\mathrm{BaK} 8)$.

Description. - A small fragment, only $18 \mathrm{~mm}$ long $(\mathrm{Wh}=$ $10.5 \mathrm{~mm}, \mathrm{~Wb}=3.8 \mathrm{~mm}$ ). The main ribs are prorsiradiate and slightly flexed, arising at faint umbilical tubercles. Rib number is increased by intercalatories. All ribs flex forwards and carry weak clavi at the umbilical margin. They join a serrated keel at an acute angle.

Remarks. - The poor preservation of this small fragment unfortunately precludes a reliable identification even if H.B. Geinitz interpreted it as Ammonites neptuni Geinitz. The compressed whorl section and ribbing pattern are in fact compatible with representatives of the Upper (but not uppermost) Turonian genus Subprionocyclus Shimizu but the previous assignment is now considered unlikely given the age of the Marterberg Member based on inoceramids (latest Turonian Mytiloides scupini Zone to early Early Coniacian). Primitive forms of the uppermost Turonian-Lower Coniacian collignoniceratid genus Barroisiceras de
Grossouvre differ from Subprionocyclus only in the absence of inner ventrolateral tubercles. Their lack may thus indicate that the specimen in question could also be a representative of that genus. Furthermore, an affinity to representatives of the collignoniceratid genera Prionocyclus Meek and Forresteria Reeside can also not completely be excluded. Therefore, and due to its very poor preservation, specimen $\mathrm{BaK} 8$ is left in open nomenclature, without generic and specific assigment.

Family Tissotiidae Hyatt, 1900

Metatissotia? sp.

Figure 12E

2009 Placenticeras? sp.; Wilmsen et al., p. 121, fig. 10E.

Material. - 1 specimen, Buchleiten Member (MMG: BaK 7).

Description. - A small fragment of a whorl with shell preservation and a length of $34 \mathrm{~mm}$. The specimen is smooth and obliquely deformed, but the originally strongly compressed whorl section and the fastigate venter with a narrow keel can still be recognised ( $\mathrm{Wh} \sim 16 \mathrm{~mm}$; $\mathrm{Wb} \sim 8 \mathrm{~mm}$ ). The ventrolateral shoulders are sharp and traces of weak clavi are present.

Remarks. - The fragmentary specimen has been illustrated as Placenticeras? sp. by Wilmsen et al. (2009, p. 121, fig. 10E). However, the central keel matches a representative of the genus Metatissotia Hyatt. This taxon is characterised by a wide range of morphological variation, and ornament declines with maturity; compressed, nearly smooth forms with fastigate venter are known from specimens as small as 50-70 mm in diameter (e.g., Kennedy 1984, p. 128, pl. 29, figs 9-11). If the generic assignment is correct, Metatissotia? sp. would most likely indicate a Middle Coniacian age (Kennedy 1984; but see comments above on the changes in Coniacian substage subdivision).

Family Baculitidae Gill, 1871

\section{Baculites sp.}

Figure 12A, B

2009 Baculites sp.; Wilmsen et al., p. 121, fig. 10H.

Material. - 2 specimens, Marterberg Member (MMG: BaK 3, BaK 4).

Description. - Two fragmentary baculitids are illustrated (specimen $\mathrm{BaK} 3: \mathrm{L}=28 \mathrm{~mm}, \mathrm{Wh}=10 \mathrm{~mm}$; BaK 4: 
$\mathrm{L}=38.5, \mathrm{Wh}=9 \mathrm{~mm}$ ) which have compressed, slowly expanding whorl sections. The dorsum is rounded and smooth. Oblique, strongly prorsiradiate ribs strengthen across the narrowly rounded venter. Some of these ribs arise at dorsolateral bullate tubercles.

Remarks. - These small baculitid fragments were identified as Baculites incurvatus Dujardin by H.B. Geinitz. However, due to the poor preservation we refrain from a specific assignment.

Family Scaphitidae Gill, 1871

Scaphites kieslingswaldensis doylei? Wright, 1979 Figure 12G

* 1979 Scaphites lamberti doylei subsp. nov.; Wright, p. 304, pl. 3, fig. 13 .

1987 Scaphites kieslingswaldensis doylei Wright, 1979. Kaplan et al., p. 13, pl. 3, figs 6-8.

2009 Scaphites kieslingswaldensis doylei? Wright, 1979. Wilmsen et al., p. 121, fig. 10G.

Material. - 1 specimen, Marterberg Member (MMG: BaK 9).

Description. - A single specimen with a height of $32.5 \mathrm{~mm}$ preserves the shaft and hook of a possible macroconch $\left(\mathrm{Wh}_{\text {hook }}=12 \mathrm{~mm} ; \mathrm{Wb}_{\text {hook }}=4 \mathrm{~mm}\right.$; length of shaft $=12 \mathrm{~mm}$; $\mathrm{Wh}_{\text {shaft }}=10.7 \mathrm{~mm}$ ). Parts of the shell are preserved. Primaries arise at the umbilical margin and have thickened bases or weak bullate tubercles on lower flanks of the shaft. Ribs branch at these swellings and again higher up on the flank, crossing the rounded venter without interruption. Weak ventrolateral tubercles are present at the transition from the shaft to the hook.

Remarks. - The present specimen is assigned to Scaphites kieslingswaldensis Langenhan \& Grundey based on its general ribbing pattern (compare Kaplan et al. 1987), but identification on subspecies level is less certain. However, the small size and the indistinct to absent ventrolateral tubercles suggest an affinity to $S$. $k$. doylei Wright, which would indicate a position high in the Upper Turonian or in the Lower Coniacian (Kaplan et al. 1987, Kaplan \& Kennedy 1996). In the proposed stratotype section of the base of the Coniacian Stage, Salzgitter-Salder in northern Germany, S. k. doylei occurs in the uppermost Upper Turonian (Wiese in Walaszczyk et al. 2010). These ranges match the inoceramid bivalve fauna, which indicates the upper Upper Turonian Mytiloides scupini Zone and the lower part of the Lower Coniacian (Tröger et al. 2009).
Phylum Echinodermata Bruguière, 1791

Class Echinoidea Leske, 1778

Subclass Cidaroidea Smith, 1984

Order Cidaroida Claus, 1880

\section{Cidaroida indet.}

? 1852 Cidaris vesiculosus Gf. - Stockheim, p. 87.

? 1868b Cidaris aff. Vesiculosa Goldf. - Gümbel, p. 759.

Material. - 1 imprint of a spine, Buchleiten Member (MMG: BaK 89).

Remarks. - The single negative of a spine fragment faintly shows the imprints of several coarse radial ridges, as commonly observed in cidaroid spines.

Order Spatangoida L. Agassiz, 1940

Family Hemiasteridae H.L. Clark, 1917

\section{Hemiaster (Bolbaster) sp.}

Figure 13

? 1852 Micraster cor anguinum Ag. - Stockheim, p. 90.

? 1868b Micraster cor anguinum Lm. - Gümbel, p. 759.

? 1881 Micraster cor testudinarium Gldf. sp. - Gerster, p. 51.

Material. - 1 specimen, Marterberg Member (MMG: BaK 110).

Description. - Only parts of the test are preserved. Test more or less rounded, relatively globose. Petals small and relatively narrow; strongly incised; three anterior petals (II, III, and IV) almost of similar size; posterior petals (I and V) slightly shorter. Peripetalous fasciole faintly visible.

Remarks. - Because of the poor preservation, a specific determination is impossible.

Phylum Brachiopoda Duméril, 1806

Order Rhynchonellida Kuhn, 1949

Family Rhynchonellidae Gray, 1848

\section{Cyclothyris? sp.}

Figure $14 \mathrm{~A}-\mathrm{C}$

? 1852 Terebratula octoplicata Sw. - Stockheim, pp. 89, 90.

? 1868b Rhynchonella plicatilis Sow., Dav. - Gümbel, p. 759.

? 1881 Rhynchonella plicatilis Sow. sp. - Gerster, p. 20.

Material. -8 specimens, Marterberg Member (MMG: BaK 81/1-8). 
Description. - Shell almost upside down cordiform to drop-shaped in dorsal view; biconvex; broadly parasulcate to uniplicate. Cardinal area of ventral valve relatively large, almost orthocline to slightly anacline; hinge line arched. Shell ornamented with 30 to 36 radial costae that are rounded triangular in cross section. Marked irregular growth lines. Pedicle opening mesothyrid to submesothyrid. Internal features unknown.

Remarks. - Given the small number of specimens available, we refrain from sectioning this unique historic material and leave the specimens in open nomenclature. Terebratula plicatilis was described from the Santonian Chalk of southern England by J. Sowerby (1816). However, it was subsequently variably assigned to Terebratula and Rhynchonella, and finally placed in the genus Cretirynchia by Pettitt (1950). In the revision of Cretirhynchia by Simon \& Owen (2001), specimens figured by Geinitz (1846, pl. 21, fig. 9a, b) as Terebratula plicatilis and Geinitz $(1873$, pl. 7, figs 5, 7, 8) as Rhynchonella plicatilis Sow. from the Upper Turonian limestone of Strehlen (Saxony) were specifically excluded from the synonymy of this taxon. The Marterberg Member specimens are quite unlike C. (Cretirhynchia) plicatilis (J. Sowerby) and show some features (costation, delthyrium) reminiscent of Cyclothyris and related taxa. The lectotype of C. (Lewesirhynchia) octoplicata (J. Sowerby, 1816) comes from the Lower Coniacian Micraster cortestudinarium Zone Chalk of Lewes (see Mortimore et al. 2001 for stratigraphic details). Again, the Marterberg material, whilst of an approximately similar age, does not compare with C. (L.) octoplicata from the Chalk (C.J. Wood, written commun.). The assignment of the specimens from the Marterberg Member to Cyclothyris? sp. is tentative and it is entirely possible that these brachiopods belong to an as yet undescribed genus.

Phylum Chordata Bateson, 1885

Class Elasmobranchii Bonaparte, 1838

Material. - 1 imprint of a shark tooth, Marterberg Member (MMG: BaK 91).

Remarks. - An indistinct imprint of a small, lamniform tooth.

\section{Class Actinopterygii Cope, 1871}

Material. - 2 scales, Buchleiten Member (MMG: BaK 92/1, 2).

Remarks. - Two small, incomplete fish scales on matrix.

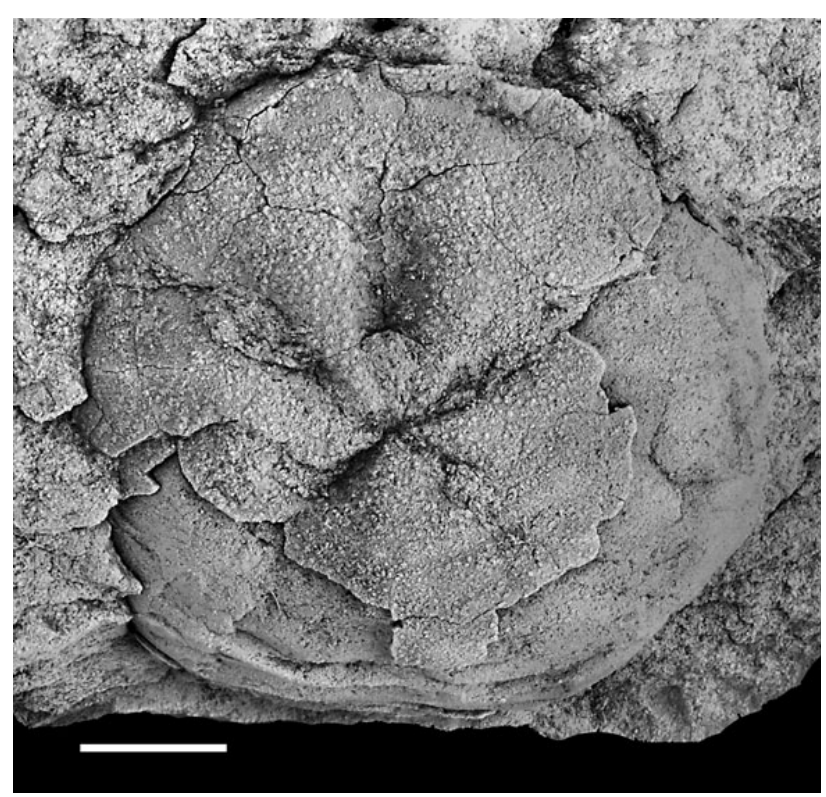

Figure 13. Echinoidea. Hemiaster (Bolbaster) sp., MMG: BaK 110. Marterberg Member. Scale bar $=10 \mathrm{~mm}$.

\section{Discussion}

The following comments clearly have to be evaluated in light of certain time-averaging of the fauna, and the absence of detailed sections with the possibility to collect bed-by-bed. However, some generalised inferences on the palaeoecology of the fauna from the Sandbach Formation are possible.

The sedimentological analysis (litho- and microfacies) of the Sandbach Formation identified silty to sandy marls and spiculitic calcisphere wacke- to packstones, both of which are suggestive of a muddy, fine-grained substrate below the normal storm wave base. This is also reflected by the occurrence of a typical soft-bottom fauna and the strong bioturbation of the sediment. Generally, the abundance of suspension and deposit feeders suggests ample food supply of particulate organic matter. For the siliciclastically dominated Marterberg Member, eutrophic conditions with turbid water masses are ascertained, while the calcisphere-rich sediments of the Buchleiten Member indicate more stable mesotrophic conditions (compare Wilmsen et al. 2005). These observations are clearly supported by the fauna: abundant bivalves, gastropods and brachiopods in the Marterberg Member versus dominant hexactinellid sponges and several bivalves in the Buchleiten Member. The gradient in nutrients may result from the continuous deepening during the deposition of the Sandbach Formation and, thus, a progressive decrease in land-derived nutrients.

The fauna of the Marterberg Member is clearly dominated by bivalves, mainly comprising epifaunal (Inoceramidae, Pectinida, Ostreida) and shallow-infaunal (Cardiidae) suspension feeders. Deep-infaunal suspension 


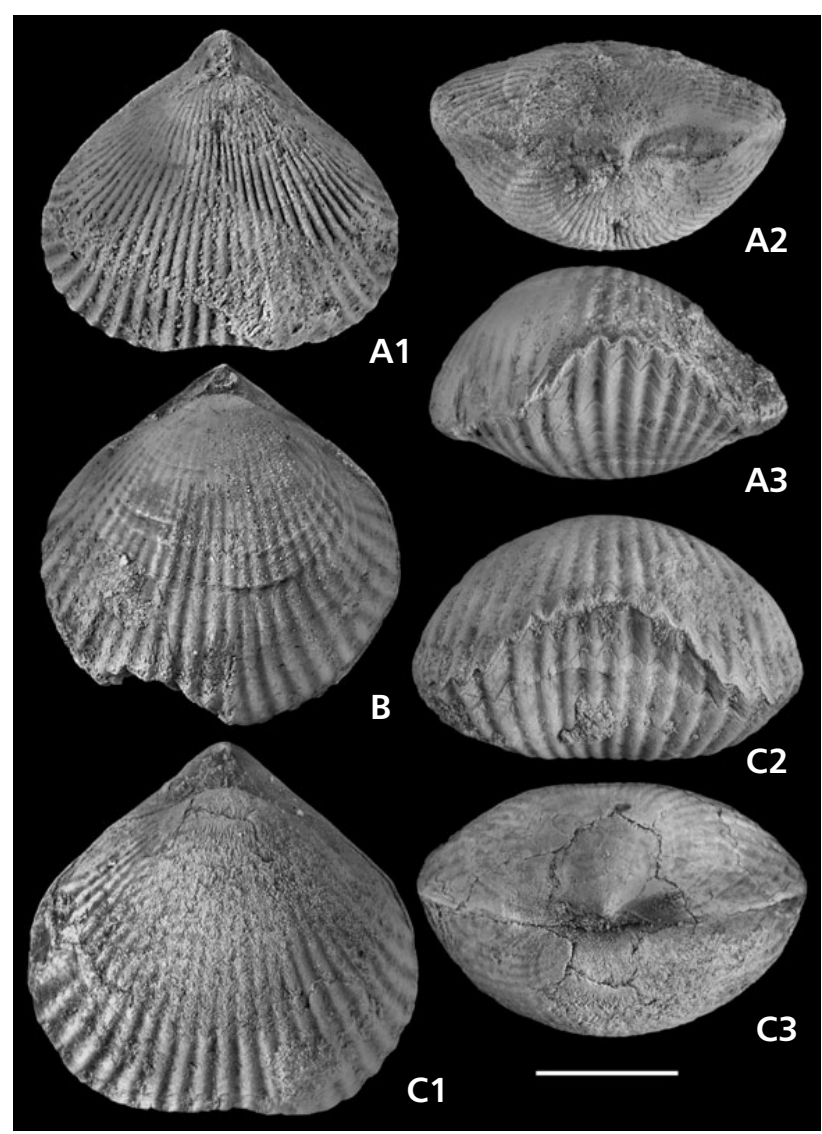

Figure 14. Brachiopoda. Cyclothyris? sp., MMG: BaK 81. Marterberg Member. Scale bar $=5 \mathrm{~mm}$.

feeders (Tellinidae) and infaunal deposit feeders (Nucula) occur subordinately. Byssate (Barbatia, Lyropecten, Anomia) or cemented forms (oysters) are small and, together with the rhynchonellid brachiopods, were certainly attached to secondary hard substrates (most likely shell fragments) throughout their lifetime. The occurrence of shallow infauna, including bivalves and irregular sea urchins, and the strong bioturbation indicate well-oxygenated bottom sediments. The high abundance of cardiids, especially those of Cerastoderma-like morphology, is strongly suggestive of relatively shallow waters, not exceeding a depth of 30-40 metres. These observations are corroborated by the gastropod fauna, which is dominated by suspension feeders (aporrhaids, Turritella) accompanied by a few herbivorous omnivores (Avellana) (Allmon 1988, Todd 2001). According to Kollmann (2009), abundant aporrhaids generally characterise distal inner to proximal outer shelf settings.

In contrast, the bottom fauna of the Buchleiten Member is predominantly composed of hexactinellid sponges. These animals, being a very conservative group since the Mesozoic, are important palaeobathymetric indicators (e.g., Oakley 1938, Reid 1968, Krautter 1997, Vodrážka \& Crame 2011). Based on comparison with fossil and recent analogues, the presence of hexactinosidan and lychniscosidan hexactinellids suggests sedimentation below the storm wave base, i.e., a minimum depth of 50-100 m. Although ecological demands of sponges with rigid skeletons could have been slightly different in the Late Cretaceous, it should be noted that in Recent environments hexactinosidan hexactinellids are almost completely absent from waters shallower that 100 m (Finks \& Rigby in Kaesler 2003).

Hexactinellid sponges are fragile suspension feeders flourishing under low sedimentation rates, which are also evidenced for the Buchleiten Member by the presence of glauconite, reduced clastic input, and the predominance of pelagic carbonate (e.g., calcispheres). The significance of a sudden occurrence of prolific hexactinellid sponges and/or lithistid demosponges during transgressive cycles has not been, however, sufficiently emphasised by previous authors. Nevertheless, numerous modern studies report Late Cretaceous hexactinellid/lithistid faunas typically linked to transgressive cycles and low sedimentation rates. The occurrence of such sponges was recently reported from the Middle Cenomanian and lowermost Turonian of the Regensburg Formation (Niebuhr et al. 2009), Lower Cenomanian of northern Germany and England (Wilmsen et al. 2005, 2007), and Lower Turonian of the Bohemian Cretaceous Basin (e.g., Žitt et al. 2006). The presence of a prolific hexactinellid sponge community in the Buchleiten Member therefore provides corroborative evidence of continuous deepening during the sedimentation of the upper part of the Sandbach Formation.

Compared to the Marterberg Member, the bivalve fauna of the Buchleiten Member is markedly depleted. All taxa are suspension feeders, most of them byssally attached or free-living epifauna. Most likely, byssate taxa were tied to the sponges, which were also colonised by juvenile oysters (Fig. 6D, E). A few infaunal bivalves also occur. The absence of cardiids as well as gastropods is striking, and may largely be explained by the continous deepening of the habitat. Similarly, gastropods are very rare in the Cenomanian offshore shelf sediments of northern Germany (Wilmsen et al. 2005, 2007).

Most of the species recorded from the Sandbach Formation also occur in Cretaceous strata of northern Germany, Saxony, Bohemia, Poland, or the Danubian Cretaceous Group (e.g., Geinitz 1839-1842, 1843, 1849; Roemer 1841; Reuss 1844, 1845-1846; Sturm 1901; Scupin 1913; Dacqué 1939). Nonetheless, only a single fauna from the Lower to ?Middle Coniacian of "Kieslingwalde" (now Idzików, SW Poland) seems to have a major portion of the taxa in common with the Marterberg Member (Geinitz 1843, Sturm 1901), indicating similar ecologic conditions. The faunal community of the Buchleiten Member is broadly similar to the fauna from the Middle Cenomanian primus Event of northern Germany described by Wilmsen et al. (2007). The primus fauna also indicates mesotrophic conditions in a deeper shelf environment at a water depth of 50-100 m. 


\section{Conclusions}

The fauna of the historical Stockheim collection (1852, housed in the Museum für Mineralogie und Geologie, Dresden) from the upper Upper Turonian-basal Middle Coniacian (Upper Cretaceous) Sandbach Formation of the Danubian Cretaceous Group (Bavaria, southern Germany) is systematically described, illustrated and discussed with respect to its stratigraphic and palaeoecological significance. The fauna provides important information on the palaeoenvironmental conditions in the area between the Franconian Alb and the Alpine system during the Late Cretaceous, which is not available nowadays due to the poor outcrop situation in the area between Passau and Ortenburg (southeast Bavaria). The Sandbach Formation comprises a lower Marterberg (upper Upper Turonian-lower Lower Coniacian) and an upper Buchleiten Member which ranges up to the Lower/Middle Coniacian boundary interval. The Marterberg Member consists of glauconitic sandy-silty marls while the Buchleiten Member comprises spiculitic calcisphere wacke- to packstones. The Sandbach Formation transgresses on Jurassic carbonates or older units of the Danubian Cretaceous Group and forms a transgressive hemi-cycle. The fauna comprises in total 53 taxa that can be attributed to Bivalvia (32 taxa), Gastropoda (7 taxa), Cephalopoda (6 taxa), Echinoidea (2 taxa), Porifera (2 taxa), Actinopterygii (?2 taxa), Brachiopoda (1 taxon), Elasmobranchii (1 taxon), and larger benthic Foraminifera (1 taxon). The fauna from the Marterberg Member is dominated by bivalves, mainly comprising epifaunal (Inoceramidae, Pectinida, Ostreida) and shallow-infaunal (Cardiidae) suspension feeders. The high abundance of cardiids as well as the trophic modes and taxonomic composition (abundant Aporrhaidae) of the gastropods strongly suggests relatively shallow waters. An eutrophic inner shelf environment below normal storm wave base with soft-bottom conditions is inferred. In contrast, the fauna from the Buchleiten Member is dominated by hexactinellid sponges and its bivalve fauna is markedly depleted. All bivalve taxa are suspension feeders, most of them byssally attached or free-living epifauna. Gastropods are completely missing and some cephalopods occur. Deposition in the aphotic zone below the maximum storm wave base in a mesotrophic mid- to outer shelf setting with low sedimentation rates is assumed.

\section{Acknowledgements}

Andrzej Kaim (München/Warszawa) and Uli Wieneke (Murnau) commented on the gastropod taxonomy. Heinz Kollmann (Wien) kindly helped with literature. Andreas Kroh (Wien) kindly checked the determination of the echinoid. Manuel Röthel and Ronald Winkler (both MMG, Dresden) provided technical sup- port. The manuscript benefited from careful reviews by John W.M. Jagt (Maastricht) and Christopher J. Wood (Minehead), who also gave valuable comments on brachiopod and ammonoid taxonomy as well as biostratigraphy.

\section{References}

ALLMON, W.D. 1988. Ecology of Recent turritelline Gastropods (Prosobranchia, Turritellidae): Current knowledge and paleontological implications. Palaios 3, 259-284.

DOI $10.2307 / 3514657$

ANDERT, H. 1913. Inoceramus inconstans Woods und verwandte Arten. Centralblatt für Mineralogie, Geologie und Paläontologie, 278-285, 295-303.

BRIART, A. \& CORNET, F.-L. 1870. Description minéralogique, géologique et paléontologique de la Meule de Bracquegnies. Mémoires couronnés et Mémoires des Savants étrangers publiés par l'Académie Royale des Sciences, des Lettres et des Beaux-Arts de Belgique 34, 1-92.

Cushman, J. 1935. Notes on some American Cretaceous flabellinas. Contributions from the Cushman Laboratory for Foraminiferal Research 11, 83-89.

DACQUÉ, E. 1939. Die Fauna der Regensburg-Kelheimer Oberkreide (mit Ausschluß der Spongien und Bryozoen). Abhandlungen der Bayerischen Akademie der Wissenschaften, Mathematisch-naturwissenschaftliche Abteilung, Neue Folge 45, 1-218.

DHONDT, A.V. 1972a. Systematic revision of the Chlamydinae (Pectinidae, Bivalvia, Mollusca) of the European Cretaceous. Part 1. Camptonectes. Bulletin de l'Institut Royal des Sciences Naturelles de Belgique, Sciences de la Terre 48(3), 1-60.

DHONDT, A.V. 1972b. Systematic revision of the Chlamydinae (Pectinidae, Bivalvia, Mollusca) of the European Cretaceous. Part 2. Lyropecten. Bulletin de l'Institut Royal des Sciences Naturelles de Belgique, Sciences de la Terre 48(7), 1-80.

DHONDT, A.V. 1973. Systematic revision of the subfamily Neitheinae (Pectinidae, Bivalvia, Mollusca) of the European Cretaceous. Mémoires de l'Institut Royal des Sciences Naturelles de Belgique 176, 1-101.

EGGER, J.G. 1907. Mikrofauna der Kreideschichten des westlichen bayerischen Waldes und des Gebietes um Regensburg. Berichte des Naturwissenschaftlichen Vereines in Passau 20, 1-75.

ELBERT, J. 1901. Das untere Angoumien in den Osningbergketten des Teutoburger Waldes. Verhandlungen des naturhistorischen Vereins der preussischen Rheinlande 58, 77-167.

FIEGE, K. 1930. Über die Inoceramen des Oberturon mit besonderer Berücksichtigung der im Rheinland und Westfalen vorkommenden Formen. Palaeontographica 73, 31-48.

FINKS, R.M. \& RIGBY, J.K. 2003. Geographic and stratigraphic distribution, 275-296. In KAESLER, R.L. (ed.) Treatise on Invertebrate Paleontology. Part E. Porifera (revised). Volume 2: Introduction to the Porifera. The Geological Society of America \& The University of Kansas, Boulder \& Lawrence.

FITTON, W.H. 1836. Observations on some of the strata between the Chalk and the Oxford Oolite, in the south-east of England. Transactions of the Geological Society, series 2, 4, 103-388.

FRIČ, A. 1889. Studien im Gebiete der böhmischen Kreideformation. IV. Die Teplitzer Schichten. Archiv für die naturwissenschaftliche Landesdurchforschung von Böhmen 7(2), 1-119. 
FrOMENTEL, M.E. de 1860. Introduction à l'étude des éponges fossiles. Mémoires de la Societé Linnéenne de Normandie 11, $1-50$.

GEINITZ, H.B. 1839-1842. Charakteristik der Schichten und Petrefacten des sächsisch-böhmischen Kreidegebirges. 116 pp. Arnoldi, Dresden \& Leipzig.

GEINITZ, H.B. 1843. Die Versteinerungen von Kieslingwalda und Nachtrag zur Charakteristik des sächsisch-bömischen Kreidegebirges. 23 pp. Arnoldi, Dresden \& Leipzig.

GEINITZ, H.B. 1846. Grundriss der Versteinerungskunde. 813 pp., 28 pls, 1 table. Arnoldi, Dresden \& Leipzig.

GEINITZ, H.B. 1849. Das Quadersandsteingebirge oder Kreidegebirge in Deutschland. 293 pp. Craz \& Gerlach, Freiberg.

GEINITZ, H.B. 1850. Notizen zur Kenntnis des Quadergebirges in der Umgebung von Regensburg. Correspondenzblatt des Zoologisch-Mineralogischen Vereines in Regensburg 4, 82-86.

GEINITZ, H.B. 1871-1875. Das Elbthalgebirge in Sachsen. Erster Theil. Der untere Quader. Palaeontographica 20(1), 1-319.

GEINITZ, H.B. 1872-1875. Das Elbthalgebirge in Sachsen. Zweiter Theil. Der mittlere und obere Quader. Palaeontographica 20(2), 1-245.

GERSTER, C. 1881. Die Plänerbildungen um Ortenburg bei Passau. Nova Acta der Kaiserlich Leopoldinisch-CarolinischDeutschen Akademie der Naturforscher 42(1), 1-59.

GoldFuss, A. 1833. Petrefacta Germaniae 1(4), 241-252. Arnz \& Co., Düsseldorf.

Goldfuss, A. 1841. Petrefacta Germaniae 3(1), 1-20. Arnz \& Co., Düsseldorf.

GÜMBEL, C.W. VON 1854. Übersicht über die geognostischen Verhältnisse der Oberpfalz. Correspondenzblatt des Zoologisch-Mineralogischen Vereines in Regensburg 8, 1-32, 37-48.

GÜMBEL, C.W. VON 1868a. Verzeichnis der in der Sammlung des zool.-mineral. Vereines in Regensburg vorfindlichen Versteinerungen aus den Schichten der Procän- oder Kreideformation aus der Umgegend von Regensburg. Correspondenzblatt des Zoologisch-Mineralogischen Vereines in Regensburg 22, 51-80.

GÜMBEL, C.W. VON 1868b. Geognostische Beschreibung des Koenigreichs Bayern. 2. Abtheilung, Geognostische Beschreibung des Ostbayerischen Grenzgebirges oder des Bayerischen und Oberpfälzer Waldgebirges. 968 pp. Justus Perthes, Gotha.

GÜMBEL, C.W. VON 1891. Geognostische Beschreibung des Koenigreichs Bayern. 4. Abtheilung, Geognostische Beschreibung der Fränkischen Alb (Frankenalb) mit dem anstossenden Fränkischen Keupergebiete. 763 pp. Theodor Fischer, Kassel.

Hallam, A. 1992. Phanerozoic sea-level changes. 266 pp. Columbia University Press, New York.

HANCOCK, J.M. \& KAUFFMAN, E.G. 1979. The great transgressions of the Late Cretaceous. Journal of the Geological Society of London 136, 175-186.

DOI 10.1144/gsigs.136.2.0175

HEINZ, R. 1932. Zur Gliederung der sächsisch-schlesischböhmischen Kreide unter Zugrundelegung der norddeutschen Stratigraphie. Beiträge zur Kenntnis oberkretazischer Inoceramen X. Jahresbericht des Niedersächsischen Geologischen Vereins Hannover 24, 23-53.

HerCogová, J. 1982. Vertreter der Gattungen Palmula und Neoflabellina in der Kreide der Böhmischen Masse. Sborník geologických věd, Paleontologie 25, 97-126.

HeRM, D., KAUfFMAn, E.G. \& Wiedmann, J. 1979. The age and depositional environment of the "Gosau“ Group (Coniacian-Santonian), Brandenberg/Tirol, Austria. Mitteilungen der
Bayerischen Staatssammlung für Paläontologie und historische Geologie 19, 27-92.

HESSEL, M.H.R. 1988. Lower Turonian inoceramids from Sergipe, Brazil: systematics, stratigraphy and paloecology. Fossils and Strata 22, 1-49.

HoOPER, J.N.A. \& VAN SOeST, R.W.M. (eds) 2002. Systema Porifera: A Guide to the Classification of Sponges. $1810 \mathrm{pp}$. Kluwer Academic/Plenum, Amsterdam.

KAPLAN, U. 2000. 3.2.9 Coniac, 78-101. In STRATIGRAPHISCHE KOMMISSION vON DEUTSCHLAND (ed.) Stratigraphie von Deutschland III. Die Kreide der Bundesrepublik Deutschland. Courier Forschungsinstitut Senckenberg 226.

KAPLAN, U. \& KENNEDY, W.J. 1994. Die Ammoniten des westfälischen Coniac. Geologie und Paläontologie in Westfalen 31, $1-155$.

KaPlan, U. \& Kennedy, W.J. 1996. Upper Turonian and Coniacian ammonite stratigraphy of Westphalia, NW-Germany. Acta Geologica Polonica 46, 305-352.

Kaplan, U., Kennedy, W.J. \& Wright, C.W. 1987. Turonian and Coniacian Scaphitidae from England and northwestern Germany. Geologisches Jahrbuch A 103, 5-39.

Kauffman, E.G., Kennedy, W.J. \& WoOD, C.J. 1996. The Coniacian stage and substage boundaries. Bulletin de l'Institut Royal des Sciences Naturelles de Belgique, Sciences de la Terre 66-Supplement, 81-94.

KeIM, G., Glaser, S. \& Lagally, U. 2004. Der letzte seiner Art - Jura und Kreide zwischen Ortenburg und Vilshofen. Geotope in Niederbayern. Erdwissenschaftliche Beiträge zum Naturschutz 4, 102.

KENNEDY, W.J. 1984. Systematic palaeontology and stratigraphic distribution of the ammonite faunas of the French Coniacian. Special Papers in Palaeontology 31, 1-160.

KenNedy, W.J., WALASZCZYK, I. \& KLINGER, H.C. 2008. Cladoceramus (Bivalvia Inoceramidae) - ammonite associations of KwaZulu, South Africa. Cretaceous Research 29, 267-293. DOI 10.1016/j.cretres.2007.04.010

KLINGER, H.C. \& KENNEDY, W.J. 1984. Cretaceous faunas from Zululand and Natal, South Africa: The ammonite subfamily Peroniceratinae Hyatt, 1900. Annals of the South African Museum 92, 113-294.

KollmanN, H.A. 2005. Gastropodes Crétacés, 176-181. In FISCHER, J.-C. (ed.) Révision critique de la Paléontologie Française d'Alcide d'Orbigny 3. Backhuys, Leiden.

KollmanN, H.A. 2009. A Late Cretaceous Aporrhaidaedominated gastropod assemblage from the Gosau Group of the Pletzach Alm near Kramsach (Tyrol, Austria). With an appendix on the taxonomy of Mesozoic Aporrhaidae and their position in the superfamily Stromboidea. Annalen des Naturhistorischen Museums Wien 111A, 33-72.

KraUtTER, M. 1997. Aspekte zur Paläökologie postpaläozoischer Kieselschwämme. Profil 11, 199-324.

KRAUS, E. 1915. Geologie des Gebietes zwischen Ortenburg und Vilshofen an der Donau. Geognostische Jahreshefte 28, 91-168.

LEHNER, L. 1924. Die Gliederung der fränkischen albüberdeckenden Kreide. Centralblatt für Mineralogie, Geologie und Paläontologie 6, 176-181.

LEHNER, L. 1933. Beobachtungen an Cenomanrelikten der südlichen Frankenalb. Studien über die fränkische albüberdeckende Kreide, II. Centralblatt für Mineralogie, Geologie und Paläontologie, Abteilung B 8, 458-470.

LEHNER, L. 1937a. Fauna und Flora der fränkischen albüberdeckenden Kreide. I. Die Lamellibranchiaten (ohne Ino- 
ceramen), herausgegeben von R. Dehm. Palaeontographica A 85, 115-228.

LEHNER, L. 1937b. Fauna und Flora der fränkischen albüberdeckenden Kreide. II. Fauna 2. Teil und Flora, herausgegeben von R. Dehm. Palaeontographica A 87, 158-230.

LINNAEUS, C. 1767. Systema naturae, per regna tria naturae, secundum classes, ordines, genera, species cum characteribus, differentiis, synonymis, locis. Editio duodecima reformata, tomus I, pars II. 533-1328. Laurentii Salvii, Holmiae.

MALChUS, N. 1990. Revision der Kreide-Austern (Bivalvia: Pteriomorphia) Ägyptens (Biostratigraphie, Systematik). Berliner Geowissenschaftliche Abhandlungen A 125, 1-231.

MEEK, F.B. 1877. Paleontology. Report of the geological exploration of the $40^{\text {th }}$ parallel. Professional Paper Engineer Dept. U.S. Army 184, 142-148.

MERCEY, M.N. DE 1872. Geologie du Canton d'Amiens. Bulletin de la Société Linnéenne du Nord de la France 1, 21.

MORTIMORE, R.N., WOOD, C.J. \& GALlOIS, R.W. 2001. British Upper Cretaceous stratigraphy. Geological Conservation Review Series 23, 1-558.

MÜlLER, J. 1851. Monographie der Petrefacten der Aachener Kreideformation. Zweite Abtheilung. 88 pp. Henry \& Cohen, Bonn.

NiEBUHR, B. 2011. Die Bohrung Pfakofen LAM B2/09 südlich von Regensburg (Turonium/Coniacium-Grenzbereich) - ein Beitrag zur Stratigraphie der Danubischen Kreide-Gruppe (Bayern, Süd-Deutschland). Geologische Blätter von Nordost-Bayern 61 (in press).

Niebuhr, B., Hiss, M., KAPlAn, U., TRÖGER, K.-A., VoIgt, S., VOIGT, T., Wiese, F. \& WILMSEN, M. 2007. Lithostratigraphie der norddeutschen Oberkreide. Schriftenreihe der Deutschen Gesellschaft für Geowissenschaften 55, 1-136.

Niebuhr, B., PÜRner, T. \& WilmSEN, M. 2009. Lithostratigraphie der außeralpinen Kreide Bayerns. Schriftenreihe der Deutschen Gesellschaft für Geowissenschaften 65, 7-58.

Niebuhr, B., WilmSEN, M., ChEllouche, P., RichardT, N. \& PÜRNER, T. 2011. Stratigraphy and facies of the Upper Cretaceous Roding Formation at the southwestern margin of the Bohemian Massif (Bavaria, southern Germany). Zeitschrift der Deutschen Gesellschaft für Geowissenschaften 162(3), 295-316.

NILSSON, S. 1827. Petrificata Suecana formationis Cretaceae descripta et iconibus illustrata. Pars prior, Vertebrata et Mollusca sistens. 39 pp. Officina Berlingiana, Londini Gothorum.

OAKLEY, K.P. 1938. Some facts about Cretaceous sponges. South-Eastern Naturalist 43, 58-61.

OHMERT, W. 1969. Die Neoflabellinen (Foraminifera) des bayerischen Coniac-Santons. Mitteilungen der Bayerischen Staatssammlung für Paläontologie und historische Geologie 9, 3-32.

ORBIGNY, A. D' 1850. Prodrome de paléontologie stratigraphique universelle des animaux mollusques \& rayonnés. Volume 2. 428 pp. Masson, Paris.

PARKINSON, J. 1811. Organic remains of a former world. An examination of the mineralized remains of the vegetables and animals of the antediluvian world; generally termed extraneous fossils. Third volume. The fossil starfish, echini, shells, insects, Amphibia, Mammalia, \& c. 455 pp. Sherwood, Neely \& Jones, London.

PETTITT, N.E. 1950. A monograph on the Rhynchonellidae of the British Chalk. Monographs of the Palaeontographical Society London, Part 1, 1-26.

PoČTA, P. (= POČTA, F.) 1883. Beiträge zur Kenntniss der
Spongien der böhmischen Kreideformation. I. Abtheilung: Hexactinellidae. Abhandlungen der Mathematisch-Naturwissenschaftlichen Classe der Königlich Böhmischen Gesellschaft der Wissenschaften 6, Folge 12(4), 1-45.

RAUFF, H. 1933. Spongienreste aus dem (oberturonen) Grünsand vom Kassenberg in Mülheim-Broich an der Ruhr. Abhandlungen der Preussischen geologischen Landesanstalt, Neue Folge 158, 1-75.

REID, R.E.H. 1964 (for 1963). The Upper Cretaceous Hexactinellida of Great Britain and Northern Ireland. Part IV. Monographs of the Palaeontographical Society London 117(3), 49-154.

REID, R.E.H. 1968. Bathymetric distributions of Calcarea and Hexactinellida in the present and the past. Geological Magazine 105, 546-559. DOI 10.1017/S0016756800055904

REUSS, A.E. 1844. Geognostische Skizzen aus Böhmen. Zweiter Band. Die Kreidegebilde des westlichen Böhmens, ein monographischer Versuch. Nebst Bemerkungen über die Braunkohlenlager jenseits der Elbe und eine Uebersicht der fossilen Fischreste Böhmens. 304 pp. C.W. Medau, Prag.

REUSS, A.E. 1845-1846. Die Versteinerungen der Böhmischen Kreideformation. Erste Abtheilung 1845, 58 pp. Zweite Abtheilung 1846, 148 pp. Schweizerbart, Stuttgart.

ROEMER, F.A. 1841. Die Versteinerungen des norddeutschen Kreidegebirges. 145 pp. Hahn'sche Hofbuchhandlung, Hannover.

RoTHPLETZ, A. 1911. Die ostbayerische Überschiebung und die Tiefbohrungen bei Straubing. Sitzungsberichte der Königlich Bayerischen Akademie der Wissenschaften, Mathematischphysikalische Klasse, 145-189.

SCHNEIDER, S. 2008. The bivalve fauna from the Ortenburg Marine Sands in the well-core „Straß“ (Early Miocene; SE Germany) - taxonomy, stratigraphy, paleoecology, and paleogeography. Paläontologische Zeitschrift 82, 402-417. DOI 10.1007/BF03184430

SCHÖNFELD, J. 1990. Zur Stratigraphie und Ökologie benthischer Foraminiferen im Schreibkreide-Richtprofil von Lägerdorf/Holstein. Geologisches Jahrbuch A 117, 3-151.

SCHRAMMEN, A. 1912. Die Kieselspongien der oberen Kreide von Nordwestdeutschland, II, Triaxonia (Hexactinellida). Palaeontographica, Supplement 5, 177-385.

SCHREYER, W. 1967. Geologie und Petrographie der Umgebung von Vilshofen/Niederbayern. Geologica Bavarica 58, 114-132.

SCUPIN, H. 1913. Die Löwenberger Kreide und ihre Fauna. $P a-$ laeontographica, Supplement 6, 1-278.

SimON, E. \& OWEN, E.F. 2001. A first step in the revision of the genus Cretirhynchia Pettitt, 1950. Bulletin de l'Institut royal des Sciences naturelles de Belgique, Sciences de la Terre 71, 53-118.

SOHL, N.F. 1960. Archeogastropoda, Mesogastropoda and stratigraphy of the Ripley, Owl Creek, and Prairie Bluff formations. Geological Survey Professional Paper 331-A, 1-151.

SOWERBY, J. 1812-1818. The mineral conchology of Great Britain; or coloured figures and descriptions of those remains of testaceous animals or shells, which have been preserved at various times and depths in the earth. Volumes $1+2.203$ pls. Benjamin Meredith, London.

STOCKHEIM, G. VON 1852. Vergleichende Übersicht der Kreidegebilde Regensburgs mit jenen der Gegend von Passau und Böhmens. Correspondenzblatt des zoologisch-mineralogischen Vereines in Regensburg 6, 83-93.

STROMBECK, A. VON 1859. Beitrag zur Kenntnis des Pläners über der Westphälischen Steinkohlenformation. Zeitschrift der deutschen Geologischen Gesellschaft 11, 27-77. 
STURM, F. 1901. Der Sandstein von Kieslingwalde in der Grafschaft Glatz und seine Fauna. Jahrbuch der Königlich Preussischen geologischen Landesanstalt und Bergakademie zu Berlin für das Jahr 1900. Abhandlungen von ausserhalb der Königlichen Geologischen Landesanstalt stehenden Personen, 39-98.

TODD, J. 2001. Gastropod diets database. http://eusmilia.geology. uiowa.edu/database/mollusc/Gastropod_diet.html [last accessed 03/2011].

TRÖGER, K.-A. 1967. Zur Paläontologie, Biostratigraphie und faziellen Ausbildung der unteren Oberkreide (Cenoman bis Turon). Teil I. Paläontologie und Biostratigraphie der Inoceramen des Cenomans und Turons Mitteleuropas. Abhandlungen des Staatlichen Museums für Mineralogie und Geologie Dresden 12, 3-207.

TRÖGER, K.-A. 1974. Zur Biostratigraphie des Ober-Turon bis Unter-Santon aus dem Schachtaufschluß der Zeche Grimberg IV bei Bergkamen. Freiberger Forschungshefte C 298, 110-130.

TRÖGER, K.-A., NIEBUHR, B. \& WILMSEN, M. 2009. Inoceramen aus dem Cenomanium bis Coniacium der Danubischen Kreide-Gruppe (Bayern, Süd-Deutschland). Schriftenreihe der Deutschen Gesellschaft für Geowissenschaften 65, 59-110.

TRÖGER, K.-A. \& SUMmESBERGER, H. 1994. Coniacian and Santonian inoceramid bivalves from the Gosau-Group (Cretaceous, Austria) and their biostratigraphic and biogeographic significance. Annalen des Naturhistorischen Museums Wien A 96, 161-197.

UNGER, H.J. 1984. Geologische Karte von Bayern 1 : 50000. Erläuterungen zum Blatt Nr. L 7545 Griesbach im Rottal. 245 pp. Bayerisches Geologisches Landesamt, München.

UNGER, H.J. \& SCHWARZMEIER, J. 1982. Die Tektonik im tieferen Untergrund Niederbayerns. Jahrbuch des Oberösterreichischen Musealvereines - Gesellschaft für Landeskunde 127, 197-220.

VODRÁŽKA, R. 2005. Rod Hillendia Reid, 1964 a Guettardiscyphia Fromental, 1860 (Porifera, Hexactinellida) z české křídové pánve. 61 pp. Unpublished M.Sc. thesis, Institute of Geology and Palaeontology, Charles University, Prague.

VODRÁŽKA, R. \& CRAME, A. 2011. First fossil sponge from Antarctica and its palaeobiogeographical significance. Journal of Paleontology 85, 48-57. DOI 10.1666/10-069.1

VODRÁŽKA, R., SKLENÁ̌̆, J., ČECH, S., LAURIN, J. \& HRADECKÁ, L. 2009. Phosphatic intraclasts in shallow-water hemipelagic strata: a source of palaeoecological, taphonomic and biostratigraphic data (Upper Turonian, Bohemian Cretaceous Basin). Cretaceous Research 30, 204-222. DOI 10.1016/j.cretres.2008.07.007

WALASZCZYK, I. 1992. Turonian through Santonian deposits of the Central Polish Uplands; their facies development, inoceramid paleontology and stratigraphy. Acta Geologica Polonica 42, 1-122.

WALASZCZYK, I. 1996. Inoceramids from the Kreibitz-Zittauer area (Saxony and northern Bohemia): Revision of Andert's (1911) descriptions. Paläontologische Zeitschrift 68, 367-392.

WALASZCZYK, I. \& SZASZ, L. 1997. Inoceramid bivalves from the Turonian/Coniacian (Cretaceous) boundary in Romania: revision of Simionescu's (1899) material from Ürmös (Ormensis), Transylvania. Cretaceous Research 18, 767-787. DOI 10.1006/cres.1997.0086

WALASZCZYK, I. \& WOOD, C.J. 1998. Inoceramids and biostratigraphy at the Turonian/Coniacian boundary, based on the Salzgitter-Salder Quarry, Lower Saxony, Germany, and the Slupia Nadbrzezna section, Central Poland. Acta Geologica Polonica 48, 395-434.
WalaszczyK, I., Wood, C.J., LeES, J.A., PeRYT, D., Voigt, S. \& WIESE, F. 2010. The Salzgitter-Salder quarry (Lower Saxony, Germany) and the Słupia Nadbrzezna river cliff section (central Poland): a proposed candidate composite Global Boundary Stratotype Section and Point for the base of the Coniacian Stage (Upper Cretaceous). Acta Geologica Polonica 60, 445-477.

WALTL, J. 1847. Briefliche Mittheilungen über die geognostischen Verhältnisse der Umgebungen von Passau und des Bayerischen Waldes oder des Böhmergebirges. Correspondenzblatt des zoologisch-mineralogischen Vereins in Regensburg 1, 29-32, 44-48.

WESSELY, G., SCHREIBER, O.S. \& FUCHS, R. 1981. Lithofazies und Mikrostratigraphie der Mittel- und Oberkreide des Molasseuntergrundes im östlichen Österreich. Jahrbuch der Geologischen Bundesanstalt 124(1), 175-281.

WIESE, F. 2000. Coniacian (Upper Cretaceous) ammonites from the North Cantabrian Basin (Cantabria, northern Spain). Acta Geologica Polonica 50, 125-144.

WiLMSEN, M. \& NiEBUHR, B. 2010. On the age of the Upper Cretaceous transgression between Regensburg and Neuburg an der Donau (Bavaria, southern Germany). Neues Jahrbuch für Geologie und Paläontologie, Abhandlungen 256, 267-278. DOI 10.1127/0077-7749/2010/0051

Wilmsen, M., Niebuhr, B., Chellouche, P., PÜRner, T. \& KLING, M. 2010. Facies pattern and sea-level dynamics of the early Late Cretaceous transgression: a case study from the lower Danubian Cretaceous Group (Bavaria, southern Germany). Facies 56, 483-507. DOI 10.1007/s10347-010-0224-2

WiLMSEN, M., NiEBUHR, B. \& HISS, M. 2005. The Cenomanian of northern Germany: facies analysis of a transgressive biosedimentary system. Facies 51, 253-274. DOI 10.1007/s10347-005-0058-5

Wilmsen, M., NiebUhr, B., WoOD, C.J. \& ZAWISCHA, D. 2007. Fauna and palaeoecology of the Middle Cenomanian Praeactinocamax primus Event at the type locality, Wunstorf quarry, northern Germany. Cretaceous Research 28, 428-460. DOI 10.1016/j.cretres.2006.07.004

Wilmsen, M., WoOD, C.J., Niebuhr, B. \& Kaplan, U. 2009. Cenomanian-Coniacian ammonoids of the Danubian Cretaceous Group (Bavaria, southern Germany). Schriftenreihe der Deutschen Gesellschaft für Geowissenschaften 65, 111-124.

WINEBERGER, L. 1851. Geognostische Beschreibung des Bayerischen und Neuburger Waldes. 140 pp. Dietenberger \& Breß1, Passau.

WoODS, H. 1899-1913. A monograph of the Cretaceous Lamellibranchia of England. Monographs of the Palaeontographical Society London, part 1: 1899-1903, 232 pp., part 2: 1904-1913, 473 pp.

WRIGHT, C.W. 1979. The ammonites of the English Chalk Rock (Upper Turonian). Bulletin of the British Museum (Natural History), Geology Series 31, 281-332.

ZITTEL, K.A. VON 1877a. Beiträge zur Systematik der fossilen Spongien. Neues Jahrbuch für Mineralogie, Geologie und Paläontologie 1877, 1-40.

ZITTEL, K.A. VON 1877b. Studien über fossile Spongien. 1. Hexactinellida. Abhandlungen der Königlich bayerischen Akademie der Wissenschaften 13(1), 1-63.

ŽítT, J., VodrÁŽKA, R., HRADECKÁ, L., SVOBOdovÁ, M. \& ZÁGORŠEK, K. 2006. Late Cretaceous environments and communities as recorded at Chrtníky (Bohemian Cretaceous Basin, Czech Republic). Bulletin of Geosciences 81, 43-79. 